\title{
Kaht u Galâda Kaht-ı Rical: Merkezî Yönetim ve Musul Vilayet İdaresinin 1879-1880 Kıtlı̆̆ıyla İmtihanı
}

\section{Deprivation of Qualified Statesmen During Famine: The Struggle of the Central Government and Mosul Provincial Administration with the Famine of 1879-1880}

\author{
Fasih DİNÇ ${ }^{1}$
}

'Sorumlu yazar/Corresponding author: Fasih Dinç (Dr. Öğr. Üyesi),

Mardin Artuklu Üniversitesi, Edebiyat Fakültesi,

Tarih Bölümü, Mardin, Türkiye

E-posta: fasihdinc@gmail.com

ORCID: 0000-0002-7213-680X

Başvuru/Submitted: 24.04 .2020

Revizyon Talebi/Revision Requested:

25.05.2020

Son Revizyon/Last Revision Received:

30.07.2020

Kabul/Accepted: 20.08 .2020

Online Yayın/Published Online: 27.11.2020

Atıf/Citation: Dinc, Fasih. "Kaht u Galâda Kaht-ı Rical: Merkezî Yönetim ve Musul Vilayet İaresinin 1879-1880 Kıtlı̆̆ıyla Imtihanı." Türkiyat Mecmuası-Journal of Turkology 30, 2 (2020): 477 503. https://doi.org/10.26650/iuturkiyat.726377

\section{öz}

Kıtlık; kuraklık ve dengesiz yağışların toplumun üretim olanaklarını ortadan kaldırmasıyla ortaya çıkan doğal bir afettir. Bu afet, her ne kadar coğrafi koşulların bir neticesi olsa da afetin giderilmesi, devlet mekanizmasının sağlıklı işleyişiyle yakından ilişkilidir. Bu mekanizmanın en önemli ayağını başarılı ve deneyimli yöneticiler oluşturmaktadır. Tespit ettiğimiz kadarıyla kıtlıkların baş gösterdiği merkezden uzak yerlerde yeterli deneyime sahip yöneticiler, memuriyet görevlerine herhangi bir leke gelmemesi için idarî sorumluluk almaktan kaçınmışlardır. Bu sebeple söz konusu yerler, daha alt düzeydeki deneyimsiz memurlar tarafından idare edilmiştir. Bu memurların afetlerden kaynaklı olağanüstü koşulların hüküm sürdüğü idarî birimlerde varlık gösterebilmeleri, sahip oldukları yetenek ile merkezî devletin yardım kapasitesiyle doğrudan ilişkilidir. Ne yazık ki olağanüstü koşullarda krizi koordine edebilme kabiliyetinden yoksun yöneticilerin merkezî hükümetten gerekli desteği de alamaması durumunda söz konusu idarî birimlerde yaşayan halk, bir trajediyle karşı karşıya kalır.

Bu çalışmada; 1879-1880 zaman aralığında şiddetli açlığın meydana geldiği Musul vilayet alanında Osmanlı merkez bürokrasinin yönetici atama yaklaşımları ile atanan yöneticilerin kıtlıkla nasıl mücadele ettikleri hususu ele alınmıştır.

Anahtar kelimeler: Kıtlık, Osmanlı Devleti, Musul vilayeti, kriz, yöneticiler

\section{ABSTRACT}

Famine is a natural disaster caused by drought and unbalanced precipitation which eliminates the production possibilities of society. Although this disaster is a result of geographical conditions, elimination of the disaster is closely related to the healthy functioning of the state mechanism. The most important pillar of this mechanism is successful and experienced administrators. As far as we ascertain in places where famine occurs, administrators with sufficient experience avoid taking administrative responsibility, as they do not want to tarnish their official duty. For this reason, the places in question are administrated by inexperienced junior civil servants. The ability of these civil servants to exist in administrative units where extraordinary conditions arise from disasters is directly related to their ability and aid capacity of the central state. Unfortunately, if the administrators lacking the capability to coordinate the 
crisis in extraordinary conditions are unable to receive the necessary support from the central government, the people living in these administrative units face a tragedy.

This study deals with the approach of the Ottoman central bureaucracy in appointing administrators and the issue of how the appointed administrators struggled against famine in the Mosul province during the severe famine between 1879 and 1880 .

Keywords: Famine, Ottoman State, Mosoul province, crisis, administrations

\section{EXTENDED ABSTRACT}

During the period from 1877 to the winter of 1879, the eastern provinces of the Ottoman Empire suffered from severe drought and famine. Although famine due to this drought increased in Van, Bitlis and Diyarbekir provinces, it was experienced in Mosul province in its most severe form, and agricultural production was completely interrupted in these regions. Successive dry season conditions from 1877 onwards led to a severe hunger in which mass deaths took place from December 1879 to May 1880.

In 1877, when the famine began, the Ottoman central government joined a fierce battle called the 93 War against the Russian State. The Ottoman Empire, which sustained a heavy defeat by Russia, suffered a great loss of land, and its economy which was in a weak state also entered into a deep crisis. One of the consequences of this war was the fact that Hakkâri Center Sheikh Ubeydullah initiated an uprising against the unsettled State authority, which also affected the area of the Mosul province. The local and international problems of the central government of the Ottoman Empire prevented measures from being taken against the famine in all eastern provinces turning into severe hunger.

In 1877, when the famine began, the Mosul, Shahrizor (Kirkuk) and Sulaymaniyah regions, which constituted the northern regions of Iraq, consisted of sanjaks under the control of Baghdad province. As the famine began to turn into severe hunger and accordingly the disturbance of the peace into a general insecurity, the central government separated these three regions from Baghdad province in 1879 and turned them into a province borough called Mosul. Kirkuk settlement was designated as the center of this province. The establishment of the Mosul province at a time when the central government was struggling with local and international crises did not allow the necessary investments to be made for the placement of a state power mechanism. As a matter of fact, almost all of the Iraqi military force which was required to prevent tribal outbursts resulting from the disturbance of the peace during the famine process had been propelled to the front. Very few of the soldiers were able to return. Most of the zaptieh forces, which provided security for settlements and government institutions, were disbanded because their salaries were not paid. This situation deprived provincial administrators of the necessary mechanisms to carry out an effective struggle against famine disaster.

Faced with the effects of famine, the central government tried to assign experienced administrators to the provincial administration. However, experienced administrators who were assigned to a province with natural disaster did not want to take responsibility for struggling 
with famine due to the concern of not being able to deliver the necessary performance. There upon the central government was forced to assign civilian administrators who wanted to gain the higher authority but lacked the necessary experience. The administrators who went to the provincial area tried to change their positions upon encountering the destruction caused by famine. Those who could not get any results resigned from their duties. Those who continued their duties and those who could not carry out the necessary struggle against famine were dismissed by the central government after complaints from the citizens.

When the central government failed to obtain the desired success from the assigned civilian administrators, it unwillingly had to leave the provincial administration to a military administrator. In fact, it was not a rare case for military officials to come to civilian positions in a region such as Iraq, geographically remote to central government. The fact that the region had a long border with Iran and accordingly threatened the peace was the source of reasons for the military officer's to take the civilian powers in addition to their own powers. The frequent occurrence of this situation led to a constant effort by the military officers to take over civilian power. Within the scope of these efforts, they refrained from working devotedly in order to leave the civilian authorities in a difficult situation whenever the peace in the province was threatened. When the civil authorities of the Mosul province failed to conduct an effective struggle against famine, the military officers took this opportunity to make contacts with the central bureaucracy, have the military officers take control of the province administration and succeeded in assigning by proxy a subordinate military officer as the administrator of Mosul.

The military officer, who was assigned by proxy as the administrator of Mosul province suffering from the famine disaster, could not achieve the necessary success due to the deep social devastation caused by the disaster. However, the military officer made contacts with the central government through a petition consisting of joint signatures of the notables of the province in order to turn the assignment of proxy into principal, but the central government avoided appointting a military officer as a the civil servant. The appointment of military officers as civilian servants had been incompatible with the state's understanding of modernization about administration since the Tanzimat reform era. As a result, the central government of the Ottoman Empire was unable to assign experienced administrators who could carry out an effective struggle against famine on the eastern borders. The inefficiency of state mechanisms and the lack of necessary administrative experience of the assigned administrators left the people of the province vulnerable to the destruction of the famine disaster. 


\section{Giriş}

Osmanlı Devleti'nin doğu vilayetlerinde; 1877 yılından 1879 kışına uzanan dönem boyunca şiddetli bir kuraklık ve buna bağlı büyük bir kıtlık meydana gelmiştir. Bu kuraklığa bağlı kıtlık; Van, Bitlis ve Diyarbekir vilayetlerinde artan düzeyde kendini göstermişse de en şiddetli hâliyle Musul vilayetinde yaşanmış ${ }^{1}$ ve bu bölgelerde tarımsal üretim tamamen durma noktasına gelmiştir. 1877'den itibaren yağışsız geçen mevsim şartları sebebiyle; 1879 Aralığından 1880 yılı Mayıs'ına dek kitlesel ölümlerle sonuçlanan şiddetli bir açlık ve yoksulluk yaşanmıştır.

Musul vilayeti karasal iklim kuşağında yer almaktadır. Vilayetin bağlı olduğu iklim kuşağında tarımsal üretim, doğanın dengesiz şartlarına bağlı olup bu şartlara en uygun ürünler buğday ve arpadır. ${ }^{2}$ Bu ürünler, vilayet alanında meskûn halkın temel besin kaynağıdır. Her iki ürün de kış mevsiminin başında ekilmekte ve bereketli nisan yağmurlarıyla boy atarak başak vermektedir. Başak zamanında ürünün bozulmadan olgunlaşması için yeterli oranda güneş 1şı̆̆ına ihtiyaç duymaktadır. Ekinin başak verdiği zamanda aşırı yağış, ürünün bozulmasına yol açabilmektedir. Ürün, yeterli yağış almadığ $\breve{g}_{1}$ takdirde de istenilen düzeyde verim elde edilememektedir. Yağış rejiminin buğday ve arpanın yetişmesine uygun olmaması veya yağmurların yıllık dağılımından kaynaklanan ölçüsüzlük, halkın temel besin kaynaklarından mahrum kalmasına yol açmaktadır. ${ }^{3}$ Neticede yağış dağılımının dengesizliği buğday ve arpa gibi tahılların yetişmesine engel teşkil ettiği gibi birbirini takip eden yılların kurak geçmesi de bütün yaşam olanaklarını yok etmektedir. Öyle ki yağışsız geçen yıllar ve akabinde doğal sulama olanağının ortadan kalkması, sadece tarımsal faaliyetlerin yapılmasına mani olmamaktadır. Aynı zamanda bitki ve otların yetişmesine de engel olmaktadır. İklimin dengesiz unsurlarına bağlı olarak ortaya çıkan bu hususlar, ${ }^{4}$ belli aralıklarla kendini yineleyen kıtlıkların oluşmasına neden olmaktadır.

Kıtlığın iklim koşullarına bağlı olarak kendini yineleyen yapısı onu herkesin ilerde karşılaşabileceği muhtemel felaketlerden biri hâline getirmektedir. Osmanlı coğrafyasında

1 “... vak'a-yı kahtın en ziyade şiddetle hüküm sürmekte olduğu mahal Musul vilayeti...” Türkiye Cumhuriyeti Devlet Arşivleri Başkanlığı Osmanlı Arşivi (BOA.) İrade Dâhiliye (İ. DH.), 802/65028, Lef. 2, 16 Ca 129 (26 Nisan 1880).

2 C. J. Edmonds, "The Kurds of Iraq", The Middle East Journal, Vol. 11, No.1, (Winter, 1957), 54; BOA. Y1ldız Esas Arşivi (Y. EE.) 7/12, 24 L 1297/29 Eylül 1880; Dr. E. Ives, A Journey From Persia to England, (London: 1773), 311; BOA. İrade Mevlis-i Vâlâ (İ. MVL.) 387/16890, Lef. 13, 9 Za 1273 (29 Haziran 1857); Musul (Vilayet) Gazetesi (MG), Say1 (S) 507, sayfa (s) 1, 5 Z 1316; Roger Owen, The Middle East in the World Economy 1800-1914, (New York: I.B. Tauris, 1993), 31.

3 Edmonds, "The Kurds of Iraq", 54.

4 Further Correspondence Respectin the Condition Of The Population in Asia Minor and Syria, Turkey No: 23 (1880), 128; Stephen Hemsley Longrigg, 'Irak, 1900 To 1950 A Political, Social, and Econmic History, (London: Oxford Universty Prees, 1956), 6; Fernand Braudel, II. Felipe Döneminde Akdeniz ve Akdeniz Dünyası, Çev. Mehmet Ali Kılıçbay, (Ankara: Doğubatı, 2017), I: 380. 
kıtlık, 19. yüzyılın sonlarına kadar daimi surette en muhtemel felaketler arasında ${ }^{5}$ yer almıştır. Nitekim 19. yüzyılın son yıllarında Musul vilayetinde meydana gelen kıtlık, yakın dönemin en yıkıcı ve korkunç felaketlerinden olmuştur. 1879-1880 yılında meydana gelen felaket esnasında binlerce insan hayatını kaybetmiş ve binlercesi de yaşam yerlerini terk ederek başka bölgelere göç etmek zorunda kalmıştır. Bunun sonucunda toplumsal ve iktisâdî yaşam altüst olmuştur. 1879-1880 kıtlığının bölgede yarattığı dram, hafızalarda uzun bir dönem canlılı̆̆ını korumuştur. ${ }^{6}$

Coğrafi etkenler kıtlığın oluşumunda temel bir rol oynamaktadır. Bununla beraber, kıtlığın yarattığı yıkıcı etkilerinin sınırlandırılması ve hatta oluşumunun engellenmesi devlet mekanizmasının yapısıyla ilişkilidir. Devletin bölgedeki konumlanma düzeyi ve teknik imkânları, coğrafi unsurların yarattığı afetlere karşı önemli bir direnç noktasını oluşturur. Bu nedenle kıtlığın oluşumu coğrafi koşullardan ziyade devletle ilişkili olarak tanımlanmaktadır. Herhangi bir bölgede devletin sahip olduğu idarî, siyasi ve ekonomik imkân/imkânsızlıklar olumsuz hava koşullarının neden olduğu kötü hasadın toplum üzerindeki etkisinin niteliğini belirlemektedir. Devletin idarî ve teknolojik imkânları ölçüsünde kıtlığın neden olduğu olumsuzluklarla mücadelede yönetici kesim kritik roller üstlenebilmektedir. Öyle ki yöneticilerin kıtlık döneminde krizi yönetmeye ilişkin ortaya koyduğu tavır ve uygulamaları, memurluk kariyerleri açısından bir sınanmaya dönüşebilmektedir.

Bu çalışmada; Osmanlı Devleti’nin Musul vilayet alanında 1877-1880 yılları arasını ihtiva eden kıtlık sürecini önleme veya tahrip gücünü sınırlandırmada sahip olduğu idarî örgütsel yapı ve bu yapının işleyişini sağlayan yöneticilerin gösterdikleri tepkiler irdelenecektir. $\mathrm{Bu}$ çerçevede çalışmada, bir taraftan merkezî hükûmetin taşrada doğal afetler sonucunda meydana gelen kriz durumunda yönetici tayinine ilişkin imkânları sorgulanmaya tabi tutulurken diğer taraftan da atanan yöneticilerin kriz karşısında iş ve hizmet görme kapasiteleri ele alınacaktır. Bu noktada 1879-1880 yılında Musul vilayetinde meydana gelen kıtlık felaketinin sadece iklimsel koşullardan kaynaklı bir durum olmadığı ortaya konulmaya çalışılmaktadır. Bunun yanında çalışma; Osmanlı Devleti'nin içinde bulunduğu mali ve siyasi krizler nedeniyle kıtlık bölgesine deneyimli yöneticiler atayamadığı, atanan yöneticilere kıtlıkla mücadele kapsamında gerekli desteği sağlayamadığı ve kıtlığın yıkıcı etkilerine karşı önleyici bir yönetim ortaya koymalarına engel olduğu iddiasını taşımaktadır.

5 19. yüzyıl insanının karşılaşabileceği muhtemel felaketlerle ilgili olarak 1843 Mayısında Mardin naibinin şer'iye siciline dercettiği dua dikkat çekicidir. Mardin naibinin sicil kaydında yaptığı duaya göre bu dönemde karşılaşabilecek ilk felaket yokluk ve düşkünlük olarak belirirken çeşitli bela ve kazaların yanında veba da bir felaket olarak tahayyül edilmiştir. Naibin duası dönemin muhtemel felaketlerinden korunma için Allaha bir yakarıştır. Bk.. İbrahim Özcoşar, Hüseyin H. Güneş, Fasih Dinç, 242 Nolu Mardin Şer ’iyye Sicili Belge Özetleri ve Mardin, (Mardin. İhtisas Kütüphanesi Yayınları, 2006), 84; Abraham Marcus, Modernliğin Eşiğinde Bir Osmanlı Şehri Halep, Çev. Mehmet Emin Baş, (İstanbul: Küre Yayınları, 2013), 21.

6 1990'da Bağdat'ta vefat eden Kerküklü yazar ve araştırmacı Şakir Sabır Zabit'in 1964'te kaleme aldığı eserinde: “1296'da açlık şimdiye kadar babalarımızdan işittiğimiz büyük baha çok acı idi” şeklindeki aktarımları söz konusu kolektif hafızanın bir yansımasını oluşturmaktadır. Bk.. Kerkük'te İçtima’i Hayat Folklor, (Bağdat: Zaman Basimevi, 1964), 111. 


\section{Kıtlık Sürecinde İdarî Ortam}

Kıtlık sürecinin şiddetli açlığa evrildiği 1879 yılına kadar Irak’ın kuzey bölgeleri, Midhat Paşa'nın 1869 yılından itibaren yürürlüğe koyduğu vilayet sistemiyle idare edilmektedir. Bu sisteme göre; kıtlığın sirayet ettiği Musul, ${ }^{7}$ Şehrizor ${ }^{8}$ (Kerkük) ve Süleymaniye ${ }^{9}$ bölgeleri, ayrı birer mutasarrıflık hâlinde Bağdat vilayetine bağlanmıştır. 1872 yılında Süleymaniye mutasarrıflıktan kaymakamlık düzeyine indirilerek Şehrizor (Kerkük) mutasarrıflığına bağlanmıştır. Irak'ın Midhat Paşa'nın Bağdat valiliğiyle başlayan yeni idarî yapılanması, 1879 yılında özellikle vilayet taksimatı yönüyle işlerliğini yitirmiş ve bu sebeple yeni bir düzenleme ihtiyacı doğmuştur. Zira tüm Irak bölgesinin Bağdat merkezli tek bir vilayet yapısıyla idare edilmesi çeşitli sorunları beraberinde getiriyordu. Irak'tan merkezî hükûmete gönderilen raporlarda, Bağdat vilayetinin çok geniş bir alanı teşkil ettiği ve valinin bu alanda gerekli denetim ve kontrolü sağlayamadığı ifade edilmiştir. Bağdat valisinin vilayetin tüm alanlarına gidememesi ve sağlıklı bir idare tesis edememesi merkezî hükûmet nezdinde de bir sorun olarak kabul görmüştür. Buna göre 1879 şubatında Bağdat vilayetinin kuzey bölgelerini teşkil eden Musul, Kerkük ve Süleymaniye sancakları müstakil bir vilayete dönüştürülmüştür. Tesis edilen yeni vilayetin merkezî de Kerkük olarak tayin edilmiştir. Musul vilayet merkezinin Kerkük olarak seçilmesinin bir nedeni de yerleşimin vilayet alanının ortasında bulunmasıdır. ${ }^{10}$ Diğer bir nedeni ise yoğun aşiret nüfusunun bulunduğu vilayette, İran sinırıyla bağlantılı aşiretlerden kaynaklı çatışmaların en tahrip edici etkisinin, Kerkük bölgesinde hissedilmesidir. Kerkük yerleşimini vilayet merkezi olarak elverişli kılan diğer bir faktör de sınırın kontrol ve denetiminde Musul ve Süleymaniye yerleşimlerine oranla stratejik konumda bulunmasıdır. ${ }^{11}$

1879 idarî düzenlemesinde Musul, Kerkük ve Süleymaniye bölgelerinin Bağdat’tan ayrılarak müstakil bir vilayete dönüştürülmesi her üç yerleşimin sakinleri tarafindan olumlu karşılanmıştır. ${ }^{12}$ Çünkü yeni oluşturulan Musul vilayeti, iyi silahlanmış ve güçlü yöneticilere sahip aşiretlerin yoğunlukta olduğu bir alanı teşkil ediyordu. Bu alanda bulunan aşiretler, kendi aralarında sürekli bir çatışma içinde oldukları gibi otorite tanımaz karakterleri nedeniyle mahallî idareyi reddetmeye hazır bir yapıya sahiptirler. ${ }^{13}$ Bölgede devlet otoritesinin zayıflaması ve meydana gelen kimi doğal afet durumlarında bu aşiret unsurlarının gerek kendi aralarında ve

7 Musul'un idarî yapısıyla ilgili daha geniş bilgi için Bk. Ahmet Gündüz, "Musul”, DİA, c. 31, (İstanbul: Diyanet Vakfi Yayınları, 2006), 363-367.

8 Şehrizor adının anlamı, coğrafi ve idarî sınırları ve Kerkük ile iliş̧isine dair geniş bilgi için Bk. Fasih Dinç, XIX. Yüzyılda Kerkük (Fiziki, İdari ve Sosyo-Ekonomik Yapı), (Doktora Tezi, Fırat Üniversitesi, 2016), 16-31; Ahmet Gündüz, "Şehrizor", DIA, c. 38, (İstanbul: DiyanetVakfı Yayınları, 2010), 473-475.

9 Süleymaniye şehrinin kuruluşu ve Osmanlı idarî teşkilatı içindeki yerine dair Bk. Ahmet Gündüz, "Süleymaniye", $D \dot{I A}$, c. 38, (İstanbul: Diyanet Vakfi Yayınları, 2010), 111-113.

10 BOA. Şurâ-yı Devlet (ŞD.) 2434/26, 21 C 1297 (31 Mayıs 1880).

11 Musul vilayetinin kıtlık süreci boyunca idarî yapısı ve meydana gelen değişimler ile ilgili olarak Bk. Dinç, XIX. Yüzyılda Kerkük, (Fiziki, İdari ve Sosyo-Ekonomik Yapı), 135-148.

12 Babı Ali tarafından Musul vilayetinin kurulmasına iliş̧in gönderilen telgrafa "tebşir" yani müjde olarak bakılmıştır. Bk.. BOA, İ. DH. 782/63625, 29 Ra 1296 (23 Mart 1879).

13 Gökhan Çetinsaya, Ottoman Administration of Iraq, 1800-1908, (London: SOAS/Routledge Studies on the Middle East, 2005), 63. 
gerekse devletin bölgesel güçleriyle çatışmaları, bölgede idarî işleyiş ve güvenliği kesintiye uğratıyordu. 1877 yılında başlayan kıtlık sürecinde Musul, Kerkük ve Süleymaniye idarî birim yöneticilerinin en aciz kaldığı hususlardan biri de aşiret taşkınlıklarıyla mücadele olmuştur. Çünkü yöneticiler, iç asayişi sağlayacak askerî güçten yoksundurlar. Bu durum, kıtlıkla beraber bölgede meydana gelen kriz durumunu daha da içinden çıkılmaz bir hâle getirmiştir. 1879' da bölgenin müstakil vilayet statüsüne kavuşması, halkın başta aşiret taşkınlıkları olmak üzere kıtlıktan kaynaklı olumsuzlukların da son bulacağı beklentisine neden olmuştur.

Musul, Kerkük ve Süleymaniye bölgelerinin müstakil vilayet ile yönetilmeye başlanması her ne kadar halkın içinde bulunduğu koşullardan kurtulma beklentilerine yol açmış olsa da vilayet avantajından faydalanma ve söz konusu avantajın sürdürebilirliğini sağlama, kabiliyetli ve dirayetli valilerin iş başına gelmesine bağlıdır. Dirayetli yöneticilerin etkin ve başarılı bir yönetim sergileyebilmeleri atandıkları alanlarda uygun koşulların bulunmasına ve onların söz konusu koşulları değerlendirebilmeleri ise merkezî hükûmetin herhangi bir kriz içinde bulunmamasına bağlıdır. Bu durum bir yönüyle yöneticilerin iyi bir talihe diğer yönüyle de merkezi bürokrasiyle güçlü bağlantılara sahip olmalarını gerektirmektedir. Bir yönetici ne kadar kabiliyetli olursa olsun atandıkları idarî birimde kıtlık, salgın hastalık veya deprem gibi afetlerle karşılaşması hâlinde o yöneticinin başarılı olma şansı oldukça düşüktür. ${ }^{14} \mathrm{Bu}$ talihsizliğe merkezî hükûmetin olağan üstü koşullar içinde olması eklendiğinde yöneticinin başarılı olması bir yana varlık gösterebilmesi bile mümkün değildir.

1877 yılında başlayan kuraklığın yol açtığı kıtlık durumu ve ondan kaynaklı olumsuz koşullar, bölgeye atanacak yöneticilerin idarî tasarruflarda bulunmasına imkân tanımayan talihsizliklerin başında gelmektedir. Buna ek olarak 1877'de devletin Rusya ile girdiği savaş, merkezî hükûmeti yerelde meydana gelen kimi olumsuzluklarla mücadele imkânından yoksun bırakmıştır. Merkezî hükûmet de bu koşullarda hâliyle mahallî yöneticileri kendi kaderlerine terk etmek durumunda kalmıştır. Kıtlık sürecinde Musul, Kerkük ve Süleymaniye bölgelerinin idarî işleyişini kesintiye uğratan aşiret taşkınlıklarına karşı mahallî idarecilerin aciz kalması, Irak askerî gücünün neredeyse tamamının savaş alanına kaydırılmasından ileri gelmiştir. ${ }^{15}$ Söz konusu gücün on binlerle ifade edildiği ve çok azının geri dönebildiği ileri sürülmüştür. ${ }^{16}$ Musul vilayet alanında kalan askerî potansiyel de kıtlı̆̆ın şiddetini artırmasıyla beraber meydana gelen olaylara müdahale edebilecek imkânlardan yoksun kalmıştır. Musul vilayetinde görevli zaptiyeler ise uzun bir dönem maaşlarını alamadıklarından ötürü çoğu dağılmış, geriye kalanlar da

14 Irak bölgesinde güçlü yöneticiler, kıtlık ve salgın hastalık gibi doğal afetlerin bulunmadığı ve ticari sirkülasyonun yoğun olduğu dönemlerde ortaya çıkmaktadır. Bk.. Tom Nieuwenhuıs, Politics And Society In Early Modern Iraq Mamluk Pashas, Tribal Shayks and Local Rule Between 1802 and 1831, (Boston/London: Martinus Nijhoff Publishers, 1982), 58.

15 J. G. Lorimer, Gazetteer Of The Persian Gulf, Oman And Central Arabia, (London: Achive Editions, 1986), 1490.

16 Ali el Vardi, Lema 'at'ül İctima 'iye, (Beyrut: Dare'l Raşid, 2005), III: 41. 
operasyona çıkabilmek için gerekli ihtiyaçlardan yoksun kalmıştır. ${ }^{17}$ Vilayet bünyesinde bulunan nizamiye askerleri de kıtlık koşullarının neden olduğu yoksunluk durumundan nasibini almıştır. Nitekim kıtlık döneminde Irak’ın Kuzey bölgesinin tümünde genel bir güvensizliğe yol açan beş yüz Hemavend aşiret mensubunun saldırılarına karşı Musul vilayet alanında konuşlandığı ileri sürülen 8 tabur nizamiye askerî hiçbir varlık gösterememiştir. ${ }^{18}$ Musul vilayetinin dağılmış askerî gücüne karşı Altıncı Ordu merkezi olan Bağdat askerî gücü de ihtiyaçları karşılamaktan uzak kalmıştır. ${ }^{19}$ Aynı şekilde orada bulunan zaptiyeler de iki yıla yakın maaş alamadıkları için görevlerini bırakmaya başlamışlardır. ${ }^{20}$ Musul vilayet alanında güvenliği sağlaması gereken askerî gücün etkili olmaktan uzak kalması ve bundan kaynaklı yöneticilerin varlık gösterememeleri, idarî birimler bünyesinde yaşayan halkın tepkisini çekmiştir. Halk asayişe ilişkin meydana gelen olaylarda, yöneticileri “seyirci gibi bakmak”la itham etmiştir. ${ }^{21}$

1877'de etkisini gösteren kuraklıkla beraber başlayan kıtlık sürecine paralel olarak 93 Harbi'nin Musul, Kerkük ve Süleymaniye bölgelerinde yarattığı otorite boşluğu, başka bir bölgesel krizin oluşmasına neden olmuştur. Kıtlığın şiddetli açlığa yol açtığı 1880 yılında Hakkâri merkezli Şeyh Ubeydullah İsyanı, yazışmalardan anlaşıldığı kadarıyla Musul vilayetinde belli ölçüde propaganda alanı bulabilmiştir. Propagandanın bölge yöneticileri tarafından anlaşılması, Şeyh Ubeydullah'ın başlattığı harekete destek olunması amacıyla bölgenin aşiret ve tarikat liderlerine gönderdiği mektuplara ulaşılmasıyla mümkün olmuştur. ${ }^{22}$ Mahallî yöneticiler, Şeyh Ubeydullah'ın propaganda mahiyetindeki çağrılarının bölgenin içinde bulunduğu olumsuz koşulları tetikleyebileceği ve kitlesel eylemlere dönüşebileceği ihtimali nedeniyle endişe ve panik içine girmişlerdir. Bu endişelerden hareketle Musul vilayet valisi ve Irak askerî erkânı, Şeyh Ubeydullah hareketinin özellikle Musul vilayetinde meydana gelmesi muhtemel kimi olaylara karşı alınacak tedbirleri merkezî hükûmete bildirmişlerdir. ${ }^{23}$

17 "Musul zabtiyelerinden çend imza ile alınan telgrafnamede zabtiyelerin 94 ve 95 senelerinden on altı aylıklarlyla sekiz aylık şıer ve saman tayinatının terâkimi ve kaht u galânın buna inzimamı cihetiyle duçar oldukları zaruretten dolayı bazıları familyalarını terk ile diyarı ahere azimet etmiş ve hayvanlarının ekserisi açlıktan telef olmuş olduğu beyan olunuyor.” Bk.. BOA. Bab-1 Ali Evrak Odası (BEO.) Vilayet Gelir Giden Defteri (VGG. d.) 966, s. 118, 15 Ca 1297 (25 Nisan 1880).

18 “...Musul vilayetinde sekiz tabur askerî nizamiye olduğu halde heyeti umumiyesi beş yüz neferi mütecaviz olmayan Hemavendlilerin hakklyla terbiyelerine bakllamaması kaht sebebiyle levazım-l seferiye-i askerîyenin tedarik-i müşkülatından neşet ederek...” Bk.. BOA. BEO. VGG. d. 966, s.126, 29 C 1297 (8 Haziran 1880).

19 Bağdat vilayet valisi Abdurrahman Paşa, merkezi hükümete gönderdiği 30 Ağustos 1880 tarihli bir raporda “...istikrarı emniyet ve asayiş vasıta-i müstakile olan kuvve-i zabtiye tensikatı umumiye sırasında bu vilayet dahi vilayat-ı saireye kıyas tutularak birkaç defa tenkih ve tenzil ile ihtiyacatı mahalliyeye kafi olamayacak bir hale ve isal edildiğinden ve silahları tebdil ve ıslah ve sair noksanlart ikmal olunmadıktan başka ... ” şeklinde vilayetin askerî potansiyelinin asayişi teminde yetersizliğini açıkça dile getirmiştir. Bk.. BOA. Y. EE. 7/12, 24 L 1297 (30 Ağustos 1880).

20 “...Vilayet zaptiyesinin sene-i sablkadan yirmiden otuz yediye kadar maaşlarl ve sene-i haliyeden dahi henüz bir akçe verilmemesinden dolayı bazı cihette bulunan efradın terki memuriyete kalkıştıkları...” Bk.. BOA. BEO. VGG. d. 966, s. 168, 20 Ş 1298 (18 Temmuz 1881).

21 BOA, Yıldız Sadaret Hususi Maruzat Evrakı (Y. A. HUS.), 164/63, 22 Ca 1297 (2 Mayıs 1880).

22 Şeyh Ubeydullah'tan Talabani Şeyhi Şeyh Ali’ye gönderilen mektup için Bk. BOA, Dâhiliye Şifre (DH. ŞFR.) 112/72, 21 N 1296 (8 Eylül 1879).

23 Bağdat'ta görevli Ferik Recep Paşa tarafından Harbiye Nezareti'ne gönderilen bir telgraf sureti için Bk. BOA, Yıldız Perakende Evrakı Askeri Maruzat (Y. PRK. ASK.) 4/55, 17 Za 1297 (21 Ekim 1880). 


\section{Kıtlık Sürecinde Vilayet Yöneticileri}

\subsection{Mutasarriflar}

Kıtlık süreci boyunca Musul, Kerkük ve Süleymaniye bölgelerine atanan yöneticileri kariyerleri açısından uygun koşulların bulunmadığı görülmektedir. Aslında merkeziyetçi politikaların uygulanmaya başlanmasıyla başta aşiretlerden kaynaklı problemler olmakla birlikte salgın gibi sorunlar, Irak bölgesini sürekli asayiş boşluğundan neşet eden bir kriz hâliyle karşı karşıya bırakmıştır. ${ }^{24}$ Bu krizlerle baş etme amacına matuf olarak mülkî yetkileri de uhdelerinde toplayan askerî erkânın yönetici olarak atanmaları söz konusu olmuştur. İdarî birimlere atanan asker kökenli yöneticiler de kendi sınıflarına mensup rütbelileri de alt idarî birimlere yönetici olarak atanması çabasından geri durmamışlardır. ${ }^{25}$ Kıtlık süreci boyunca Musul sancağı hariç Kerkük ve Süleymaniye sancakları askerî erkâna mensup Paşa unvanlı mutasarrıfların uhdelerinde görülmektedir.

Mülkî ve askerî yetkilerin ayrıştırılmasına karşı çıkan ve asayiş problemlerini çözebilme kapasitelerine sürekli vurguda bulunarak mutasarrıflık yetkilerini ellerine almaya çalışan asker kökenli yöneticilerin, ${ }^{26}$ kıtlıktan kaynaklanan olumsuz koşullar karşısında mülkî kökenli yöneticilere oranla fark edilebilir bir başarı gösteremedikleri anlaşılmaktadır. Nitekim kıtlık süreci boyunca Kerkük ve Süleymaniye sancaklarının mutasarrıfları birkaç sefer değişmekle beraber Musul sancağının mutasarrıflığını yürüten Nazım Efendi, sürecin sonuna kadar görevini sürdürmüştür. Merkezî hükümetin kendisini kıtlıktan mustarip başka bir bölgeye tayin etmesi teşebbüsüne direnen Nazım Efendi, mevcut görev alanının dışına çıkmayacağını, aksi bir durum karşısında da görevinden ayrılacağını bildirmiştir. Nazım Efendi’nin Musul'dan ayrılmamasına yönelik kesin tutumunu gören merkezî hükûmet, geri adım atarak kıtlık sürecinin sonuna kadar kendisini Musul mutasarrıflık görevinde bırakmak durumunda kalmıştır. ${ }^{27}$ Nazım Efendi kıtlığın şiddetlendiği dönemde halkın beklentilerine cevap verebilecek bir yönetim sergileyebilme

24 Modernleşmenin devlet idarî yapısına dayattığı temel olgu merkezileşmedir. Merkezileşmenin süregelen devlet yapısında meydana getirdiği değişim beraberinde başkaldırı gibi tepkilere neden olmuştur. Bu tepkilerin meydana getirdiği düzensizlik ve bozulma hâli modernleşmenin doğal bir sonucu olarak değerlendirilmektedir. Bk.. S. N. Eisenstadt, Modernleşme baş̧kaldırı ve değişim, Çev. Ufuk Coşkun, (Ankara: Doğubatı, 2004), 34.

25 Kerkük'ün de dâhil olduğu Bağdat vilayetine bağlı sancaklara yapılan mutasarrıf atamalarının ordu hiyerarşisi içinden Ferik rütbesine haiz olanlar içinden atandığı görülmektedir. Bk.. BOA, Bağdad Ayniyat, d. 851, s. 151, 5 Ca 1289 (11 Temmuz 1872); Fırka-yı askerîye kumandanlığ ilave olunarak Şehrizor (Kerkük) mutasarrıflı̆̆ına Nafiz Paşa'nın tayini. Bk.. BOA. İ. DH, 633/47598, 8 Ra 1291 (25 Nisan 1875).

26 Askerî erkânın Irak'ın imar ve düzeninin sslahı ile ilgili olarak merkezî hükûmete gönderdikleri raporlarda mülkî ve askerî hizmetlerin birbirinden ayrılmasının Irak idaresi için sıkıntı yarattığı belirtilmektedir. Mülkî memurların iktidarsızlıkları ve dirayetsizliklerinden dolayı asayişin sağlanamadığı ve bunun da ziraî ve ticarî faaliyetlere doğrudan yansıması sonucu bölgede arzu edilen ilerlemenin elde edilemediği savunulmuştur. Bk.. BOA. Y. EE. 12/8, 25 B 1296 (15 Temmuz 1879).

27 Kıtlık süreci boyunca Musul, Kerkük ve Süleymaniye sancaklarına yapılan mutasarrıf atamaları için Bk. BOA. BEO. VGG. d. 966, s. 21, 24 L 1295 (21 Ekim 1878); BOA. BEO. VGG. d. 966, s. 66, 4 B 1296 (24 Haziran 1879); BOA. İrade Mesail-i Mühimme (İ. MMS), 62/2915, Lef. 2, 17 C 1296 (8 Haziran 1879). 
olanağı bulamamakla ${ }^{28}$ beraber kıtlık süreci boyunca gösterdiği sabır ve direncinden olsa gerek merkezî hükûmet tarafından bir üst rütbe ile taltif edilmiştir. ${ }^{29}$

Kıtlık sürecinin Bağdat ve daha sonra da Musul vilayetine bağlı sancaklar içinde en sert geçtiği yerler, Kerkük ve Süleymaniye sancaklarıdır. Zira kıtlığın Musul’dan Kuzey’e doğru yayılan alanlardaki etkisi daha kötüydü. Bu bölgedeki aşiretler, mutasarrıfların yöneticilik iradelerini sınayan en temel unsur olmuştur. Kerkük ve Süleymaniye mutasarrıfları, aşiretlerin kontrol altına alınmasında gerekli önlemleri alamadıkları ve asayiş sorunlarıyla baş edemedikleri yönünde merkezî hükûmet nezdinde şikâyet konusu olmuşlardır. ${ }^{30}$ Süleymaniye sancağı bu anlamda en fazla sorunla karşılaşan sancak olmuştur. Bu koşullardan dolayı Eylül 1878'de görevde bulunan Ziver Paşa, Süleymaniye'de daha fazla kalamayacağını merkezî hükûmete bildirerek görevden affını istemiştir. ${ }^{31}$ Kendisinden sonra Kerkük sancağı mutasarrıflığından Süleymaniye sancağına geçen Ferik Sabit Paşa ile ilgili olarak da Caf aşireti ile yaşanan sorunlar dolayısıyla Süleymaniye sancağında daha fazla kalmasının "mazarratı melhuz" ciddi sorunlara neden olacağı yönünde merkezî hükûmete şifreli telgraf gönderilmiştir. ${ }^{32}$ Sabit Paşa, daha sonra kıtlık nedeniyle karşılaştığı ağır koşullardan dolayı merkezî hükûmetten ailesini İstanbul'a nakletmek için altı ay süreyle izin istemiş ve kıtlığın şiddetlendiği bir dönemde yerine vekil bırakarak Süleymaniye'den ayrılmıştır. ${ }^{33}$ Daha sonra kendisi görev alanına dönmüş ve görevinde göstermiş olduğu dirayetten dolayı Beylerbeylik rütbesini almaya muvaffak olmuştur. ${ }^{34}$

Musul ve Süleymaniye mutasarrıfları kıtlık sürecinde devlet olanaklarının yetersizliğine karşı halkın mağduriyetini giderme yolunda yeni olanaklar yaratamadıkları gibi onların, süreç boyunca halkın en fazla şikâyet konusu ettiği asayişin temini konusunda, taltifi gerektirecek olağanüstü bir performans gösterdiklerine ilişkin verilerle karşılaşılmamıştır. Hatta kıtlık sürecinin başından sonuna kadar Musul'da görevli bulunan Nazım Efendi, mahallî imkânların tükendiği en şiddetli zamanda bile yeni olanakların sağlanması konusunda merkezî hükûmeti bilgilendirmemiştir. Üstelik bu durumun vilayet birimlerinde görevli bulunan bütün idarî yöneticiler için de geçerli olduğunu bölgeden geçen bir seyyah ifade etmiştir. ${ }^{35}$ Örneğin Süleymaniye mutasarrıflık alanında kıtlığın şiddetlenmesi ve acı haberlerin art arda merkezî hükûmete ulaşmasıyla birlikte merkezî hükûmet, olayların bu raddeye gelmeden önce sürece ilişkin gerekli bilgilendirmelerin

28 Lieutenant-Colonel Miles 'tan Sir A. H. Layrad'a, Musul, 19 Ocak 1880, Further Correspondence Respectin The Condition Of The Popülation İ Asia Minor And Syria, Turkey No: 23 (1880), s. 95; Binbaş1 Melis tarafindan 19 Kanunisânî 80 tarihli Musul'dan gönderilen telgraf için Bk. BOA. Hariciye Nezareti Tercüme Odası (HR TO.) $258 / 30,19$ Ocak 1880.

29 BOA. BEO. VGG. d. 966, s. 156, 30 Ra 1298(2 Mart 1881).

30 “Kerkük ile Süleymaniye’nin işleri fevkalade karışık bir halde ...” Bk.. BOA. İ. MMS, 62/2915, Lef. 2, 17 C 1296 (8 Haziran 1879).

31 BOA. DH. ŞFR, 119/6, 1 L 1296 (28 Eylül 1878).

32 BOA. DH. ŞFR, 111/27, 18 Ca 1296 (10 Mayıs 1879).

33 BOA. DH. ŞFR, 113/54, 23 Ca 1297 (3 Mayıs 1880).

34 BOA. İ. DH, 812/65561, 22 N 1297 (28 Ağustos 1880); BOA. BEO. VGG. d. 966, s. 136, 24 N 1297 (30 Ağustos 1880).

35 Major Trotter'dan the Marguis of Salisbury'ya, 3 Mart1880, Further Correspondence Respectin The Condition Of The Popülation In Asia Minor And Syria, Turkey No: 23 (1880), s. 110. 
neden yapılmadığı hususunda mutasarrıfa yüklenmiştir. ${ }^{36}$ Süleymaniye mutasarrıflığına karşı tutumundan hareketle merkezî hükûmetin, kıtlığın önünün alınamamasında yöneticilerin gerekli bilgilendirmelerde bulunmamasının payı olduğu düşüncesini taşımadığını söylemek mümkündür. Zira merkezî hükûmet böyle bir kanaat taşısaydı, mutasarrıfı hemen azletmesi ve gerekli soruşturmaya tabi tutması gerekirdi. Ancak merkezî hükûmet kıtlığın idareciler üzerinde yarattığı baskının farkında olarak onları görevlerinden aflarını isteyecek duruma getirmemeye çalışmıştır. Hatta yukarıda ifade edildiği gibi söz konusu baskıya, tek başına göğüs germeleri nedeniyle başarılı bulup ödüllendirme yoluna gitmiştir.

\subsection{Valiler}

Kıtlık sürecinin ilk iki yılında Bağdat vilayetine ve daha sonra da Musul vilayetine bağlı Musul, Kerkük ve Süleymaniye sancaklarının mutasarrıflar açısından ihtiva ettiği olumsuz koşullar, sürecin açlığa doğru gittiği bir dönemde her üç sancağın müstakil bir vilayete dönüşmesi nedeniyle valiler için de kariyer sınama alanına dönüşmüştür. Bölgenin olumsuz koşulları, ilerleyen süreçte daha da ağırlaşmıştır. Merkezî hükûmet yeni teşkil ettirdiği vilayet alanında bulunan olumsuz koşullarla mücadele etmek için tecrübeli gördüğü yöneticileri atamaya çalışmış, ancak vilayetin içinde bulunduğu zor koşullardan haberdar olan söz konusu yöneticiler, vilayete atanmamak veya atamalarını durdurmak amacıyla çeşitli gerekçeler ileri sürerek görevi üstlenmekten imtina etmişlerdir. Nitekim bu kapsamda Musul valiliğine 3 Şubat 1879'da atanan eski sadrazamlardan Hamdi Paşa'nın ${ }^{37}$ bu görevi kabul etmediği 6 gün sonra valiliğe yapılan yeni bir atamadan anlaşılmaktadır. 9 Şubat'ta vilayet valiliğine üst düzey bürokratlardan Mahmud Nedim Paşa ${ }^{38}$ atanmıştır. Ancak Mahmud Nedim Paşa da Musul gibi uzak bir memlekete ilerleyen yaşını ve sağlık sorunlarını gerekçe göstererek gidemeyeceğini ifade etmiştir. ${ }^{39}$ Yeni teşkil edilen vilayetin içinde bulunduğu olumsuz şartlara karşı güçlü vali arayışlarından ${ }^{40}$ sonuç alamayan merkezî hükûmet, nihayet 14 Şubat 1879 tarihinde gerek bölge gerekse valilik tecrübesi olmayan Şehremaneti Nan-1 Aziz Komisyonu'nun geçici başkanlığını yürüten eski Turhal mutasarrıfı Feyzi Paşa'nın vilayet valiliğine atanmasına karar vermiştir. ${ }^{41}$

1879 Şubat'ının ortalarında Musul vilayetine tayin edilen Feyzi Paşa'nın, görev yerine ulaşır ulaşmaz, kıtlıktan kaynaklı karşılaştığ 1 tablodan olsa gerek İstanbul'a geri dönmenin çabası içine girmeye başladığı görülmektedir. Paşa, İstanbul'a geri dönme çabalarına gerekçe olarak

36 BOA. BEO. VGG. d. 966, s. 94, 10 Z 1296 (25 Kasim 1879).

37 BOA, Y. EE, 4/11, 10 S 1296/3 Şubat 1879.

38 Mahmud Nedim Paşa'nın biyografisi için Bk. Ali Akyıldız, "Mahmud Nedim Paşa”, DİA, c. 27, (Ankara: Diyanet Vakfi Yayınlar1, 2003), 374-376.

39 Musul valiliğine nasp buyrulan devletlû Mahmud Nedim Paşa hazretleri dahi bilad-ı ba'ideye azimette vucudça imkân ve iktidarsızlığından bahisle affinı isti 'taf etmiş olduğundan... Bk. BOA. İ. DH, 781/63488, Lef. 2, $16 \mathrm{~S}$ 1296 (9 Şubat 1879).

40 Taşra vilayetlerine üst düzey bürokratların tayinini, II, Abdülhamit'in merkezden uzaklaşmasını istediği kişiler için başvurduğu bir strateji olarak da tanımlanmaktadır. Bk.. Carter V. Findley, Osmanlı İmparatorluğunda Bürokratik Reform, Çev. Ercan Ertürk, (İstanbul:Tarih Vakfı Yurt Yayınları, 2014), 270.

41 BOA. İ. MMS, 60/2850, 21 S 1296 (14 Şubat 1879). 
“arıza-i vücudiyesi” yani sağlık sorunlarını göstermiştir. Merkezî hükûmetten sağlık sorunlarının baş göstermesi nedeniyle “muvakkaten” İstanbul'a dönmesi için izin talebinde bulunmuş ve söz konusu talebinin dikkate alınmaması durumunda "valilikten affina” müsaade edilmesini istemiştir. Ancak Feyzi Paşa'nın geçici bir süreliğine İstanbul’a dönüş talebi Meclis-i Vükelâ tarafından yapılan müzakerede Musul vilayetinin İstanbul'a olan uzaklığı gerekçesiyle kabul edilmemiştir. ${ }^{42}$ Feyzi Paşa’nın İstanbul'a dönüş için ileri sürdüğü sağlık sorununa karşı Musul vilayetinin uzaklığı gerekçesiyle ret edilmesi, Meclis-i Vükelâ üyelerinin Paşa tarafından ileri sürülen mazereti kabul etmediklerine göndermede bulunmaktadır. Çünkü hasta olan birisinin uzak bir mesafeyi kat etmesi sağlık sorununu daha da kötüleştirebileceğinden hastanın bundan imtina etmesi gerekmektedir. Ancak hasta olduğunu iddia eden kişi ileri sürdüğü hastalığına karşı uzun bir yolculuğa çıkma isteğini ısrarla vurgulamaktadır. Bu durum muhtemelen Meclis-i Vükelâ üyelerinin Paşa'nın ileri sürdüğü gerekçeye şüpheyle yaklaşmasına neden olmuştur. Nitekim Paşa'nın İstanbul'a geri dönmesi talebinin kabul görmemesine gösterilen bir başka gerekçe ise vilayetin içinde bulunduğu kritik koşullardır. ${ }^{43}$ Bu koşullar her ne kadar İstanbul'a dönüş gerekçesi olarak Feyzi Paşa tarafından ifade edilmemiş olsa da Meclisi Vükelâ heyetince o bölgenin "ehemmiyeti dahi derkâr bulunması" şeklinde dolaylı bir anlatımla belirtilmesi, Paşa'nın vilayetten ayrılma talebinin hastalıktan ziyade kıtlık koşullarından ileri geldiği ihtimalini akla getirmektedir. ${ }^{44}$ Bu ihtimalden kaynaklı olsa gerek meclis, Feyzi Paşa'nın İstanbul'a dönüş talebini uygun bulmamıştır. Ancak Paşanın ayrılma 1srarı ve gerektiğinde görevden alınması talebi meclisi, Musul vilayet valiliğine uygun birinin tayin edilmesine sevk etmiştir. ${ }^{45}$

Meclis-i Vükelâ, Feyzi Paşa'dan boşalacak göreve Mamûretülaziz mutasarrıfı Abdünnafi Efendi' yi uygun görerek 27 Nisan 1879 tarihinde atamasını yapmıştır. Merkezî hükûmet, kıtlığın şiddetli açlığa doğru yol aldığı bir dönemde, valilik tecrübesine haiz birini hâlâ Musul vilayetine atamaya muvaffak olamamıştır. Bundan kaynaklı olsa gerek Feyzi Paşa’nın vilayetten bir an evvel çıkış yapma çabalarına karşı Abdünnafi Efendi'nin görev yerine gitmek için herhangi bir çaba göstermediği anlaşılmaktadır. Normal koşullarda merkezî hükûmet, olağan üstü koşulların hüküm sürdüğü ve uzun bir idarî boşluğu kaldıramayacak kadar hassas olan Musul vilayeti gibi bir idarî birime ${ }^{46}$ atadığ 1 yöneticinin bir an evvel göreve başlaması eğiliminde olmuştur. Yine herhangi bir idarî göreve atanan yöneticinin maaşı, atandığı yerde göreve başladıktan

42 BOA. İ. MMS, 60/2850, 21 S 1296 (14 Şubat 1879).

43 Musul'un ba'idiyet-i mesafesi cihetiyle vali-i müşarün ileyhin muvakketen Dersaadete gelmesi caiz olmayub... Bk. BOA. İ. MMS, 64/3040, 4 Ca 1296 (26 Nisan 1879).

44 19. yüzyılın sonlarında bile mülkî idarenin kurumsal yapısı, taşradaki bir memuru belirli aralıklarla İstanbul'a gitmekten ve kişisel bağlantıları yoluyla atama veya yer değiştirmeye ilişkin işleyişi kendi lehine çevirmekten alıkoyacak bir düzeye erişememiştir. Bk.. Carter V. Findley, Kalemiyeden Mülkîyeye Osmanlı Memurlarının Toplumsal Tarihi, Çev. Gül Çă̆alı Güven, (İstanbul: Tarih Vakfı Yurt Yayınları, 1996), 313.

45 ... şununla beraber bu aralık oraların ehemmiyeti dahi derkar bulunmasına binaen müşarün ileyhin affiyla yerine diğer münasip bir zatın tayini lazım gelmiş... Bk. BOA. İ. MMS, 64/3040, 4 Ca 1296 (26 Nisan 1879).

46 Oliver Bouquet, Sultanın Paşaları 1839-1909, Çev. Devrim Çetinkasap, (İstanbul: Türkiye İş Bankası Yayınları, 2016), 441. 
sonra ödenmeye esas alındığından ${ }^{47}$ bir an önce görev yerine ulaşmayı kendisi için elbette yararlı görmektedir. Ancak merkezî hükûmetin, 27 Nisan 1879 tarihinde Musul vilayetine vali olarak tayin ettiği Abdünnafi Efendi’nin görev yerine gitmediği ve Feyzi Paşa'nın yaklaşık 6 ay daha valilik görevini sürdürdüğü anlaşılmaktadır. Sebebi belirtilmemekle beraber 27 Nisan'da yapılan atamanın gereği icra edilememiştir.

Meclisi Vükelâ'nın Musul vilayet valiliğine ilişkin idarî tasarrufu neden icraya konulmamıştır? Sorusu yanıt bulması gerekmektedir. Valiliğe ataması yapılan Abdünnafi Efendi'nin hangi gerekçelerden dolayı görev yerine gitmediğinin yanı sıra Feyzi Paşa'nın görevden ayrılmasına müsaade edilmesi talebine rağmen vilayetten ayrılmamasının nedenlerine ilişkin ulaşılabilen kayıtlarda herhangi bir veriyle karşılaşılmamıştır. Bununla birlikte dönemin atama ve yer değiştirme idarî tasarruflarının genel uygulamaları çerçevesinde bu duruma, bir izahat getirilebilir. Bu dönemde herhangi bir göreve atanan mülkî memur, atandığ görevin gereğini karşılayamaması durumunda Feyzi Paşa örneğinde olduğu üzere görevden kaçmak veya idarî yetersizliğe ilişkin herhangi bir algıya meydan vermeden bazı idarî mazeretler gerekçe göstererek görevden ayrılma talebini dile getirebilmektedir. ${ }^{48}$ Aynı şekilde bir mülkî memur, merkezî hükûmet içinde bulunan bürokratik bağlantılarını kullanmak suretiyle başka bir görev için bir çaba içine girebilmekte ve bu çabalarından bir sonuç alma ümidi dâhilinde görev yerinde kalabilmeyi yeğleyebilmektedir. ${ }^{49} 27$ Nisan atamasının icraya konulamaması durumuna da söz konusu genel uygulamalar çerçevesinde iki ihtimale dayandırmak suretiyle şöyle bir izahat getirmek mümkündür. Birincisi Feyzi Paşa'nın İstanbul'a geri dönmeye ilişkin ileri sürdüğü mazeretin uygun bulunmaması üzerine yeni bir yer bulununcaya kadar görevini sürdürmek zorunda kaldığı düşünülebilir. İkincisi ise Abdünnafi Efendinin atandığı görevi doğrudan reddetmek yerine merkezî hükûmet nezdinde kendi bağlantılarını devreye sokarak memuriyet kariyeri açısından daha uygun koşullara sahip bir yer ayarlama ${ }^{50}$ ümidiyle atama yerine gitmemeye matuf olarak ağırdan alma yoluna başvurduğu söylenilebilir.

27 Nisan 1879'da yapılan atamanın icabının yerine getirilememesi hangi gerekçelerden kaynaklı olursa olsun merkezî hükûmet, Musul vilayetinin içinde bulunduğu kritik koşullarla

47 Herhangi bir göreve atanan memurun maaş ödemesine ilişkin hesaplamalar göreve fiili olarak başlamasıyla yapılmaktadır. Örneğin Musul mutasarrıfının Kerkük’e nakline ilişkin atamasında; “...işe mübaşereti tarihinden itibaren maaşının itasına” şeklinde ifade edilmiştir. Bk.. BOA. Sadaret A.).d. 982, Numara 48, 23 Şubat 1298 (7 Mart 1883).

48 Bk.. BOA. İ. MMS, 64/3040, 4 Ca 1296 (26 Nisan 1879).

49 Osmanlı memur atamalarının uygulanmasına ilişkin 19. yüzyılın son on yılında yapılan değerlendirme için Bk. M. Şükrü Hanioğlu, Bir Siyasal Örgüt Olarak Osmanlı İttihad ve Terakki Cemiyeti ve Jön Türklük, (İstanbul: İletişim Yayınları, 1989), I: 63-64.

50 Abdünnafi Efendi memuriyet hayatı boyunca atandığı görevleri merkezi bürokrasiyle kurduğu yakın ilişkiler ile elde ettiği Divanında; Niyaz-nâme Be-Dergâh-ı Merhum Müşarün İleyh Bera-yı Takeb-i Me 'muriyet, Berâ-yı Taleb-i Me'muriyet Be-Canib-i Nazır-ı Maliye-i Esbak Merhum Muhtar Paşa, Be sitan-ı Sadr-ı Esbak Merhum Müşarün İleyh Berâ-yı Taleb-i Me 'muriyet başlıklarıyla yer alan kasidelerden açıkça anlaşılmaktadır. Bk.. Emrah Gündüz, Abdünnâfi İffet Efendi ve Divanı, (Doktora Tezi, Atatürk Üniversitesi, 2018), 11. 
mücadele istek ve azminde bir valiyi görevlendirme konusundaki sıkıntıları giderememiştir. ${ }^{51}$ Aslında normal koşulların hüküm sürdüğü zamanlarda bile merkezî hükûmet, Irak bölgesi dâhil bütün doğu vilayetlerine nitelikli yönetici atamasında sıkıntılar yaşamıştır. Çünkü tecrübeli yöneticiler, şark hizmetine ilişkin korkular taşımışlardır. ${ }^{52}$ Dolayısıyla Feyzi Paşa, vilayet valiliğini yürütme isteksizliğine ve görevden ayrılma 1srarına rağmen görevini yürütmeye devam etmek durumunda kalmıştır. Paşa'nın vilayetin içinde bulunduğu olumsuz koşullar nedeniyle görevini isteksiz yürütmesi vilayet yönetimi ile ilgili kimi zaman merkezî hükûmetle yüksek dozda gerilimlere neden olmuştur. Merkezî hükûmetle karşı karşıya kaldığı gerilimlerden bir tanesi Şeyh Ubeydullah sorunuyla mücadele kapsamında Van valisiyle bir sürtüşme içine girmesi üzerine yaşanmıştır. Van valisinin bu sürtüşmeyi merkezî hükûmetin gündemine taşıması üzerine Feyzi Paşa Dâhiliye Nezareti tarafından ihtar edilmiştir. Kıtlıktan kaynaklı vilayet alanında meydana gelen aşiret taşkınlıklarını önleyemediği için merkezî hükûmetin zaman zaman yaptığı uyarıların $^{53}$ yanında Dâhiliye Nezaretinin ihtarı eklenince Paşa'nın sinirleri iyice bozulmuştur. Nitekim Paşa, Nezaretin ihtarına karşı Kerkük merkezinden gönderdiği telgraf suretlerinde önce vilayet valiliğinden affını istemiş daha sonra da üslubunu sertleştirerek affımı istid'a değil azlimi azlimi arz ederim ${ }^{54}$ gibi beyanla diyaloğunu bir meydan okumaya kadar götürmüştür.

Kıtlık sürecinin ilerlemesinin Musul vilayetinde yarattığı olumsuz koşullar, valinin idarî imkân ve kabiliyet sınırlarını iyiden iyiye zorlamış ve bu durum merkezî hükûmetle resmi ilişkilerini tamamen bozmuştur. Nihayetinde Feyzi Paşa, merkezî hükûmete istifasını sunmuş ve merkezî hükûmet 20 Kasım 1879’da istifasını kabul etmiştir. ${ }^{55}$ Feyzi Paşa’nın Musul valiliğinden

51 Merkezî hükûmet vilayetin içinde bulunduğu koşullarla mücadelede bu dönem itibariyle sadece ehil vali atayamama sorunlarıyla karşı karşıya kalmamıştır. Vilayete bağlı kazalara da merkezden kaymakam atayamamaktadır. Nitekim Eylül 1879’da Musul vilayet merkezi olan Kerkük’e yakın Köysancak kazasına atadığı kaymakam adayı görev yerine gitmekten imtina etmiş ve merkezî hükûmet vilayet valisine orada uygun birinin kaymakam olarak seçilmesini istemek zorunda kalmıştır. Bk.. BOA. BEO. VGG. d. 966, s. 94, 11 L 1296 (28 Eylül 1879).

52 Abdülhamit Kırmızı, Abdülhamid'in Valileri Osmanlı Vilayet İdaresi 1895-1908, (İstanbul: Klasik Yayınları, 2016), 56.

53 Bu uyarılardan birine yönelik Feyzi Paşa'nın verdiği cevap için Bk. BOA. Hariciye Siyasi (HR. SYS), 2942/ 19, 13 Ş 1296 (2 Ağustos 1879); Bu dönemde aşiretlerin çıkardığı taşkınlıklara karşı merkezî hükûmetin uyarılarına sadece Musul valisi maruz kalmamıştır. Bağdat valisi de bu tür sorunlardan dolayı bazı nezaretler tarafından uyarılmıştır. Nitekim bunlardan iyice bunalan vali Dâhiliye Nezaretine gönderdiği telgraf suretinin giriş kısmında içinde bulunduğu durumu: ... nezaretinin muamelesinden bizarlığım artık tasdi'i mecburiyet verdi. Verilen emirlerin... na kabil olduğu telgraf ve mektuplar ol kadar mütehakkimane ki mütehammil bir memuru bizar eyler... şeklinde dile getirerek bıkkınlığını açıkça belirtmiştir. Aynı telgrafın son kısmında ise; ... Nezaret-i müşarün ileyhaya icabı veçhiyle ihtarat buyrulmaz ve kendisi de ta'dil-i muamele etmez ise ba'dema yazılacak şeylerden cevabsız bırakılub mütekabele edeceğimi arz ederim.... diyerek bağlı olduğu nezaretten gerekli girişimlerde bulunulmasını aksi takdirde karşılı̆̆ın kendisi tarafından verileceğini dile getirmesi Feyzi Paşa'da görülen sinirlilik ve meydan okuma hâlini yansıtmaktadır. Bk.. BOA. DH. ŞFR, 111/96, 26 B 1296 (16 Temmuz 1879).

54 BOA. DH. ŞFR, 112/50, 5 N 1296 (23 Ağustos 1879).

55 BOA. BEO. VGG. d. 966, s. 94, 5 Z 1296 (20 Kasim 1879); BOA, İ. MMS, 64/3040, 4 Z 1296 (19 Kasim 1879). Bu dönemde kıtlıktan kaynaklı olarak merkezî hükûmet kurumlarıyla yaşanan sorunlar sadece Feyzi Paşa’ya özgü değildir. Nitekim Feyzi Paşa'nın istifasından bir gün önce Altıncı Ordu müşiri de benzer sorunlar nedeniyle görevinden ayrılmış yerine askerî erkândan biri vekil olarak görevlendirilmiştir. Bk.. BOA, BEO. VGG. d. 966, s. 94, 4 Z 12967 (19 Kasim 1879). 
ayrılması yazışmalardan takip edilebildiği kadarıyla vilayet alanında kıtlığın şiddetlenmesine paralel olarak merkezî hükûmetle yaşadığ gerilimlerin sonucunda gerçekleşmiştir. ${ }^{56}$ Ancak istifasına yol açan nedenlere ilişkin yazışmalara yansıyan açık ifadelere rağmen Feyzi Paşa'nın Musul valiliğinin, onun vefatıyla nihayet bulduğu da iddia edilmiştir. ${ }^{57}$ Söz konusu kayıt ve iddialar, Feyzi Paşa'nın istifasının hemen ardından vefat ettiğine işaret etmektedir. Yalnız vefatının, görevi devralmasının hemen başında İstanbul'a geri dönmeye gerekçe olarak belirttiği sağlık sorunundan mı, görev yerinde zuhur eden başka bir hastalıktan mı ya da farklı nedenlere ilişkin olarak verilerden hareketle bir şey söylemek pek mümkün değildir. Ulaşılabilen kayıtlarda istifasına yol açan nedenler arasında sağlıktan kaynaklı herhangi bir vurgu veya beyana rastlanılmamıştır. Paşa'nın, istifa nedenine yönelik bir sağlık problemini gerekçe olarak ileri sürmemesi, merkezî hükûmetin daha önce vilayetten ayrılma amacına ilişkin öne sürdüğü sağlık sorununu bahane olarak değerlendirmesinin yarattığı çekinceden ileri gelmiş olabilir. Netice itibariyle Feyzi Paşa'nın istifasını; kıtlık koşullarının gittikçe kötüleşmesi sonucunda vilayet yönetiminde ortaya çıkan sorunların giderilmesine yönelik merkezî hükûmetin kurduğu baskılar ile bu dönemde zuhur eden hastalığının kendisini güçten düşürmesiyle ilişkilendirmek mümkündür.

Feyzi Paşa'nın istifasının merkezî hükûmet tarafından kabul edilmesiyle birlikte Musul valiliğine Abdünnafi Efendi atanmış ve görev yerine intikal edinceye kadar da valilik vekâleti uygun birine verilmiştir. ${ }^{58}$ Musul vilayeti için uygun görülen Abdünnafi Efendi'nin atanmasına esas teşkil eden hususiyetler arasında sicil kaydından hareketle tecrübeli devlet adamı olması ve icra ettiği görevlerde başarılı bir yönetici olması vurgulanmıştır. ${ }^{59}$ Tecrübeli yönetici vasfi kudemayı ricâl-i devlet tabiri ile ifade edilmiştir. Abdünnafi Efendi'nin idarî becerileri kapsamında her ne kadar tecrübelilik vasfı ön plana çıkarılmışsa da Musul vilayet valiliği kariyerindeki ilk valilik görevini teşkil etmektedir. Bununla beraber "Efendi" ${ }^{60}$ unvanından anlaşıldığı üzere ilmiye sınıfına mensuptur ${ }^{61}$. Yani mülkîyeye sonradan intisap etmiştir. ${ }^{62}$ İlmiye kökenli memurların tebdil-i tarik veya tebdil-i meslek olarak da adlandırılan mülkîyeye

56 “... Feyzi Paşa hazretlerinin vuku’-l istifasına mebni azliyle...” Bk. BOA. BEO. VGG. d. 966, s. 94, 5 Z 1296 (20 Kasim 1879).

57 Davut Hut, Musul Vilayetinin İdari, İktisadi ve Sosyal Yapısı ( 1864-1909), (Doktora Tezi, Marmara Üniversitesi, 2006), 106.

58 BOA. BEO. VGG. d. 966, s. 94, 5 Z 1296/20 Kasim 1879.

59 Abdünnafi Efendinin 1879 Nisanının sonlarında yapılan ilk atamasında sicil kayıtlarından hareketle vurgulanan özellikleri; “... kudemâ-yı rical-i devlet-i aliyyeden ve şimdiye kadar bulunduğu memuriyetlerde ibrazı hüsn-i hizmet etmiş bendegân olması cihetiyle ... ” şeklinde dile getirilmiştir. Bk.. BOA. İ. MMS, 64/3040, 4 Ca 1296/26 Nisan 1879.

60 Efendi unvanının kullanım ve anlamına ilişskin Bk. Mehmet Zeki Pakalın, Osmanlı Tarih Deyimleri ve Terimleri Sözlüğ̈̈, (İstanbul: MEB, 1993), I: 505-506.

61 Abdünnafi Efendi'nin ilmiye sınıfına mensubiyetini gösteren bir diğer kanıt da kendisinin tercüme ve şerh ettiği Mizan'ül-Burhan adlı eserin basılması konusunda yaptığı müracaatlardan anlaşılmaktadır. Bk.. BOA. Maarif Mektubi Kalemi (MF. MKT.), 71/72, 12. 11. 1298 (6 Ekim 1881).

62 Abdünnafi Efendi'nin mülkiyeye intisabının 1846 yılında kendisinin İstanbul'a gelmesi ve orada yürüttüğü bürokratik temasları sonucunda verdiği dilekçeyle gerçekleştiği belirtilmektedir. Bk.. İbnülemin Mahmud Kemal İnal, Son Asır Türk Şairleri, (İstanbul: MEB, 1969), II: 1065. 
transferleri, 19. yüzyılın kaht-i ricalden kaynaklanan bir özelliğidir. ${ }^{63}$ Dolayısıyla Abdünnafi Efendi’nin kıtlık şartlarının egemen olduğu bir vilayet alanına atanacak birinde aranan tecrübeli ve başarılı memur profilinin gereklerini icra edebilecek yeterlilik ve donanıma sahip olmadığı söylenilebilir. Abdünnafi Efendi’nin olağan üstü hâlin hüküm sürdüğü bir vilayet için yeterli derecede mesleki birikime veya en azından valilik tecrübesine sahip olmamasının yanında ihtiyar denebilecek bir yaşta olması onun tecrübeli ve başarılı yönetici profilini kısıtlayan başka bir unsur olarak karşımıza çıkmaktadır.

Kıtlık şartlarının şiddetli açlığa dönüşmeye başladığı bir zamanda Musul vilayet valisi olarak atanan Abdünnafi Efendi, kıtlıktan kaynaklı olağanüstü şartların hâkim olduğu Musul vilayet valiliğini üstlenmekle memurluk kariyerindeki başarılı siciline halel getirebileceği kaygısını taşımış mıdır? Bu soruya ulaşılan veriler üzerinden cevap verebilme olanağı bulunmamakla birlikte çok ciddi bir risk almış olduğu ifade edilebilir. Bununla birlikte Osmanlı bürokrasi dünyasında bazen risk alınmadan statü alınamamaktadır. Herkesin taliplisi olduğu bir yere, bir mutasarrıfın vali olarak atanması güçlü bir bürokratik çevreye sahip olmayı gerekli kılar. Kaldı ki bu tür yerler ekseriyetle sadrazamlık gibi üst düzey görevleri icra etmiş kesimin takibinde bulunan yerlerdir. ${ }^{64}$ Hayatının son safhalarında ancak mutasarrıflığa intisap edebilmiş Abdünnafi Efendi gibi mülkî bir memurun ekonomik ve sosyal şartların uygun olduğu bir vilayete vali olarak terfi etmesi imkânsız olmamakla birlikte bir hayli güçtür. ${ }^{65}$ Dolayısıyla Musul vilayet valiliği, bütün risklerine rağmen Abdünnafi Efendi'nin mutasarrıflıktan valiliğe terfisi noktasinda bir firsat mahiyetindedir.

19 Kasım'da atanan Abdünnafi Efendi'nin atamasının yapıldığı sırada ikamet yeri kaynaklardan hareketle tespit edilemediğinden görevine ne zaman başladığı da bilinememektedir. Ancak kaba tahminle bir aydan aşağı olmayacağını söylemek mümkündür. Bu şiddetli açlığın ve bundan kaynaklı trajik olayların yaşanmaya başlandığı zaman dilimi olan aralık ayının sonlarına tekabül etmektedir. Vilayet halkı ise validen mevcut sorunlarının çözümü yolunda görünür bir çaba beklemektedir. Zira aşiret taşkınlıkları bilhassa Hemavend aşiretinin eşkıyalık eylemleri vilayet içinde seyahat ve ulaşımı durma noktasına getirmiştir. ${ }^{66}$ Vilayette asayiş sorunlarından dolayı ortaya çıkan genel güvensizlik durumu ${ }^{67}$ ve bundan kaynaklı yardımların

63 Kırmız1, Abdülhamid'in Valileri Osmanlı Vilayet İdaresi 1895-1908, 84.

64 Musul vilayetinin ilk teşkil edildiği dönemde valiliğine sadrazamlık görevinde bulunmuş Nedim Paşa atanmıştır. Ancak Nedim Paşa vilayetin uzaklığını ve ileri yaşından dolayı sağlığının el veremeyeceğini gerekçe göstererek bu görevden affını istemiştir. Nedim Paşa'nın vilayete atanması üst düzey görevlerde bulunanların valilik görevi beklediklerine bir örnek teşkil etmektedir. Bk.. BOA. İ. MMS, 60/2850, 21 S 1296 (14 Şubat 1879).

65 Valilik makamında ekseriyetle merkezi idareden veya vilayet yönetiminden gelenler istihdam edilmektedir. Bk.. Bouquet, Sultanın Paşaları 1839-1909, 427.

66 BOA. Yıldız Mütenevvî Maruzat Evrakı (Y. MTV.), 3/129, 24 C 1297 (3 Haziran 1880).

67 Musul vilayetinin Mart ayı vukuatı jurnaline göre bir ay zarfında Kerkük’te 35, Süleymaniye Sancağında ise 33 vukuat kayıtlara yansımıştır. Bu vukuatlar; nehb, sirkat, gasb ve katl şeklinde kayıt altına alınmıştır. Meydana gelen söz konusu suçların faili olarak aşiret eşkıyası şeklinde düşürülen kayıt az değildir. Bk.. BOA. Hariciye Nezareti Tahrirat (HR TH.), 34/28, Lef 8, 17 Ca 1297 (27 Nisan 1880). 
ihtiyaç bölgelerine ulaştırılamaması $1{ }^{68}$ vali olarak Abdünnafi Efendi'yi tepkilerin esas muhatabı kılmıştır. Bu tepkilerin izlerini kıtlığa maruz kalan şairlerden takip etmek mümkündür. Bu anlamda en belirgin tepkiyi Kerküklü şair Şeyh Rıza vermiştir. Hicivleriyle meşhur Şeyh Rıza, Abdünnafi Efendi'nin valiliğini şöyle hicv etmiştir:69

\section{Musul vilayet oldu Nâfi Efendi vali \\ Vaveyletülvilâye vaveyletül ahâli}

Bu beyittin farklı bir biçimde derlenmiş hâli ise şöyledir.

\section{Musul oldu vilayet Nâfi Efendi vali \\ Veylün lekum ra'iyye kül başına ahâlî}

Abdünnafi Efendi'nin valiliğinin ilk beş ayında kıtlığın yıkıcı etkisi günden güne artmış ve nihayetinde büyük bir felakete dönüşmüştür. Bu felaketi önlemek bir valinin imkân ve kapasitesini aşan bir durum olmakla birlikte en azından felaketin etkilerini hafifletme noktasındaki beklentilere cevap vermesi beklenmektedir. Beklentilerinin karşılığını mahallî yöneticilerden alamayan halk yönünü merkezî hükûmete çevirmiştir. Merkezî hükûmet, Abdünnafi Efendi'nin yetersizliğini Bağdat vilayet imkânlarına başvurmak suretiyle telafi etmeye çalışmıştır. Bu amaçla merkezî hükûmet, Bağdat vilayet idaresine Musul vilayet halkının 1stırabına neden olan kıtlık felaketi ile bu felaketin yol açtığ Hemavend aşiret saldırılarının önüne geçilmesinin, hükûmetin bir görevi olduğunu ifade etmiş ve onlardan gerekli önlemlerin alınmasını istemiştir. ${ }^{70}$ Merkezî hükûmetin Abdünnafi Efendi’ye yardımcı olunmasına ilişkin talebinin Bağdat vilayetince ne şekilde karşılık bulduğu tam anlamıyla takip edilememekle birlikte bu talep, halkın, Abdünnafi Efendiye yönelik şikâyetlerinin önünün alınmasına engel olamamıştır. Hatta bundan sonraki süreçte halktan, açlığın etkileriyle mücadele edebilme kapasitesine sahip bir valinin atanması talepleri gelmeye başlamıştır. ${ }^{71}$

Musul vilayet halkı, içine düştükleri kıtlık felaketinden kendilerini kurtarmaya dönük bir validen beklentilerini, Abdünnafi Efendi'nin yetersizliklerinden hareketle dillendirmişlerdir. Bu kapsamda, halkın Abdünnafi Efendi'nin idarî yönlerini şikâyet konusu ettiği en belirgin özelliği yaşlılığıydı. Çünkü valinin yaşlılığı vilayetin çeşitli yerlerinde felakete dönüşen kıtlıktan kırılan halkın durumunu bizzat görmeye mâni olmaktadır. ${ }^{72}$ Kaldı ki 1871'de çıkarılan vilayet

68 Yardımların ihtiyaç mahalline ulaştırılamaması neticesinde "...Musul için Bağdad'dan erzak tertib ve irsal olunmak üzere ise de o taraflarca yolların emniyetsizliği ... zehayir sevkine mâni olduğu ihtar olunuyor. Memlekette bu kadar ihtiyaç var iken zahire celbinin işkal edilmesi badi-i teessüf olduğundan def'i ihtiyaç için lazım gelen tedabirin kemali sür'atle icrası için bı 't-tekrar nazarı dikkatleri celb ediyor. "şeklindeki ifadelerle vali uyarılmıştır. Bk.. BOA. BEO. VGG. d. 966, s. 116, 11 Ca 1297 (21 Nisan 1880).

69 Atâ Terzibaşı, Kerkük Şairleri, Ötüken Neşriyat, Ankara 2013, s. 305.

70 "Kahtın def'i ve mesabin-i ahalinin tehvin-i lzdırabı emrinde tedabir-i lazımenin icrast mehattim-i vazife-i hükümet olmakla bu vazifenin hüsn-i ifast için gayret olunması ve Hemavend aşiretinin men'i șekaveti hakkinda Bağdad vilayetine icra-yl tebliğat...” Bk.. BOA. BEO. VGG. d. 966, s. 120, 1 C 1297 (11 Mayss 1880).

71 BOA. Y. A. HUS, 164/63, 22 Ca 1297 (2 Mayıs 1880).

72 At sırtında vilayeti arşınlayan hareketli valiler mükemmel yönetici olarak tanımlanmaktadır. Bk.. Bouquet, Sultanın Paşaları 1839-1909, 407. 
kanuna göre; vali vilayetinde yılda iki defa teftiş gezisine çıkmakla mükellef kılınmıştır ${ }^{73}$. Felaketten kıvranan halkın, devletin en üst düzey temsilcisi tarafindan ziyaret edilmemesi ve vilayetin özellikle asayiş sorunlarında hareket halinde olamaması, valinin yaşlılığını en temel ve görünür sorun hâline getirmiştir. Halkın yerel makamlara yansıyan taleplerini merkezî hükûmete yansıtan bir belge suretinde, Abdünnafi Efendi'nin ahlakî ve ilmî açıdan saygıya değer bir zat olmakla beraber musince yani yaşlı olmasının şikâyet konusu olmasına neden teşkil ettiği belirtilmiştir. Bundan dolayı Musul'a daha cerbezelice ve genç bir zatın hemen isali lazımeden olduğu ifade edilmiştir. ${ }^{74}$ Musul halkı yaşlı vali figüründen, anlaşıldığı kadarıyla, hoşlanmamaktadır. Zira Şeyh Rıza’nın, Abdünnafi Efendi’nin kendisine mi veya başka bir yaşlı valiye mi yönelik olduğu anlaşılamayan bir başka hicvi, yaşlı vali figürüne yönelik tahammülsüzlüğü açıkça göstermektedir. Şeyh Rıza yaşlı vali figürünü şu şekilde hicv etmiştir: ${ }^{75}$

Yaşl yüzden mütecaviz bir vali

İşte bundan bozulur memleketin ahvâlî

Memleket uslahına bir meyyiti etmiş memur

Âferîn kuvve-i idrâkıne Bâb-ı âlî

Abdünnafi Efendi'nin felaket boyutuna ulaşan kıtlıkla mücadele konusundaki yetersizliğine yönelik şikâyetlerde ön plana çıkarılan diğer yönleri; gerekli idarî deneyime sahip olmaması ile devlet otoritesini sağlayamamasıdır. Abdünnafi Efendi'nin bu yetersizliklerine ilişkin şikâyetler halkın merkezî hükûmete yönelik yeni vali taleplerinde vurguladıkları özelliklerle açığa çıkmaktadır. 1880 Mayıs'ında başlayan şikâyetlerin muhtevasında vilayet halkı, içinde bulundukları duruma çare üretebilecek valinin sahip olması gereken vasıflarını iktidarı mücerreb olan veya muktedir ${ }^{76}$ tabirleriyle dile getirmişlerdir. Vilayet halkınca başarılı vali figürü mücerreb yani valilik deneyimine sahip olma ile asayişin sağlanması için gerekli otoriteye sahip olma kabiliyetine atıfta bulunan muktedir kavramlarıyla dile getirilmiştir.

Abdünnafi Efendiye ilişkin vilayet halkından merkezî hükûmete yansıyan şikâyet ve taleplerin 1880 yılının Mayıs ayında başladığı görülmektedir. Mevsim hasadının felaketin açtığı yaraları gidermekten çok uzak bir potansiyel teşkil etmesinin görülmesi, vilayet halkını mahallî yöneticilerin kabiliyet ve tasarruflarına daha fazla bağımlı kılmıştır. Buna mukabil Abdünnafi Efendi'nin kabiliyet ve iş görme kapasitesinden halkın hiçbir beklentisi kalmamıştır. Zira valinin devletin koruyucu kanatlarını bırakın sıradan halka, vilayetin alt birimlerinde görevli müdür ve kaymakamlara dahi açamadığı görülmüştür. Nitekim Kerkük’ten Yıldız Sarayına çekilen telgraftan, bölgede yaşanan kıtlıktan ölen bir hayli kaymakam ve müdürün

73 Roderic H. Davison, Osmanlı Imparatorluğu'nda Reform 1856-1876, Çev. Osman Akınhay, (İstanbul: agora kitaplı̆̆ $1,2005,166$.

74 BOA. Y. A. HUS, 164/63, 22 Ca 1297 (2 Mayıs 1880).

75 Şeyh Rıza Talabani, Divan-ı Şeyh Rıza-yı Talabani, (Bağdat: Çaphane-i Maarif, 1946, 254.

76 “Musul valiliğine kahttan mesab olan ahâlîsinin ta 'mir-ü'l-ahvaline muktedir bir zâtın gönderilmesi ..." isteğine ilişkin olarak Bk. 164/63, 22 Ca 1297 (2 Mayıs 1880). 
olduğu anlaşılmaktadır. ${ }^{77} \mathrm{Bu}$ durumun yarattığg umutsuzluktan olacak ki; vilayet halkı başka bir valinin tayin edilmesine yönelik taleplerini Mayıs ayından itibaren daha açıktan dillendirmeye başlamıştır. Bu kapsamda Musul valiliği için ilk olarak Basra vilayet valiliğini yürüten Sabit Paşa'nın becayiş yoluyla Musul'a kaydırılması önerisi gündeme gelmiştir. Ancak merkezî hükûmet bu fikre sıcak bakmamıştır. Merkezî hükûmete göre Basra vilayeti önemli bir vilayet olup Sabit Paşa da bu vilayetin idaresinde oldukça başarılı bir yönetim sergilemektedir. $\mathrm{Bu}$ bağlamda merkezî hükûmet tarafından onun Basra valiliğinden alınması vilayet yönetimi açısından doğru görülmemektedir. Bununla beraber Abdünnafi Efendi’nin Musul vilayetinin içinde bulunduğu sorunları izale edebilecek bir kapasitesinin olmadığı da dolaylı bir şekilde kabul edilmiştir. Zira Musul vilayetine daha genç ve dinamik bir valinin atanmasının uygun olacağını ifade edilmiştir. ${ }^{78}$

1880 mayısından itibaren Abdünnafi Efendi’nin vilayet valiliğinden alınması ve daha etkin bir yöneticinin tayin edilmesine yönelik başlayan talep ve öneriler haziran ayında da devam etmiştir. Haziran başında vilayet sınırları içinde meskûn bir aşiretin baş muhtarı ile müderrisi Kerkük’ten çektikleri telgrafta; “ ”... şu fenalı̆̆ın ıslahı idare-i huzure ile hasıl olacă̆ meydandadır. Vikayemizle ahval-ı devlete şefkaten vilayetimizin idaresine iktidarı mücerreb olan Taki Paşa'nın tayiniyle umumuzun ihyasına müsare'at buyrulması müsterhemdir." ifadelerini sarf ederek, maruz kaldıkları felaketin izalesinin ancak asayişin sağlanması ile mümkün olabileceğini ve bunun da yeterli derecede tecrübeye sahip Taki (Takiyüddin) Paşa'nın vilayete vali olarak atanmasıyla sağlanabileceğini ifade etmişlerdir. ${ }^{79}$

Musul vilayet halkının sergilenen yönetimden rahatsızlıklarını çeşitli vesilelerle dile getirmesine karşın Abdünnafi Efendi, merkezî hükûmetten belirli aralıklarla vilayet merkezinin Kerkük'ten Musul'a taşınmasını talep etmiştir. Abdünnafi Efendi, vilayetin içinde bulunduğu olumsuz koşullarla sağlıklı bir şekilde mücadele edilememesini “... matlub olan kavaid ve muhsenatın husulüne layıkıyla hizmete elverişli bir mevki olmadı̆̆ından...” ifadelerinde de görüldüğü üzere vilayet merkezi olan Kerkük'ün yeterli alt yapı ve donanıma sahip olmamasına bağlamıştır. ${ }^{80}$ Vali, makul düzeyde bir hizmetin sağlanabilmesi koşulunun Musul vilayet merkezinin Kerkük’ten Musul'a taşınmasıyla mümkün olacağını vurgulamıştır. Ancak merkezî hükûmet Abdünnafi Efendi'nin kıtlıktan kaynaklı olumsuz koşullarla mücadelenin, Musul şehrinin vilayet merkezi olmasıly yapılabileceği düşüncesine destek vermemiştir. Merkezî hükûmet vilayet merkezinin değişimi konusunu "merkezin tahvili ilerude düşünülecek mevaddan olup..." ifadeleriyle reddederek daha sonra görüşülmesi gereken konulardan saymış ${ }^{81}$ ve Abdünnafi Efendi’ye bir bakıma mevcut koşullar içinde çalışmasını salık vermiştir.

77 ... kaht-ı meclubun .... kesb ettiği fenalı̆̆ın deracâtı sinemiz içinde nice kaymakamla müdir katl olunduğuyla anlaşıllyor ...” Bk. BOA. Y. MTV. 3/86, Lef. 2, 29 Ca 1297 (9 Mayıs 1880).

78 BOA. Y. A. HUS, 164/63, 22 Ca 1297 (2 May1s 1880).

79 BOA. Y. MTV, 8/87, 21 R 1299 (12 Mart 1882).

80 BOA. ŞD, 2434/26, 21 C 1297 (31 Mayıs 1880).

81 BOA. ŞD, 2434/26, Lef. Lef. 1, 24 L 1297 (29 Eylül 1880). 
Kıtlığın yarattığı asayiş sorunlarıyla gerekli mücadeleyi icra edememesine yönelik şikâyetlere rağmen Abdünnafi Efendi’nin valilik görevini Temmuz ayının başına kadar yürüttüğü görülmektedir. ${ }^{82} \mathrm{Bu}$ tarihten sonra onun görevine ilişkin durumu takip edilememektedir. Ancak Ağustos ayı başlarında görevden ayrılmış olduğu anlaşılmaktadır. Zira Musul valiliğine vilayetin içinde bulunduğu olağanüstü koşullarla baş etme konusunda gerekli deneyime sahip olduğu düşünülen Müşir Fuat Paşa'nın atanmasına ilişkin merkezî hükûmete öneride bulunulmuştur. Fuat Paşa'nın Musul valiliğine tayinine ilişkin merkezî hükûmete yapılan öneriye gerekçe olarak kendisinin daha önce bölgede askerî firka kumandanlığını yürütmüş olması gösterilmiştir. ${ }^{83}$ Musul vilayetinin de içinde bulunduğu Irak bölgesinin kendisine özgü otorite tanımaz yapısı, görevlendirmelere ilişkin gerekçelerde bölgede çalışma deneyimine atıfta bulunmayı gerekli kılmaktadır. ${ }^{84}$ Çünkü bölgenin sosyo-politik yapısına vakıf olmayan yöneticilerin başarılı bir profil sergilemeleri zordur. Osmanlı merkezî hükûmeti de yönetici atamalarında Irak bölgesinin kendine özgü yapısını dikkate almaktadır. Bundan dolayı mülkî atamaların, ya bölgede bulunan zatlardan ya da daha önce burada çalışmış olanlar arasından yapılmasına özen gösterilmiştir. ${ }^{85}$

Merkezî hükûmet, normal şartlar altında bile yönetilmesi zor olan Musul vilayetine felaket boyutuna ulaşmış olan kıtlığın hüküm sürdüğü bir zamanda bölge deneyimine sahip bir yöneticiyi atamak için çaba göstermektedir. Söz konusu çabaya bağlı olarak bölgede çalışma deneyiminin yanı sıra vilayet valiliğine asker kökenli bir ismin ön plana çıkmış olması, bölgede kıtlıktan dağılmış olan devlet otoritesini sağlayabilme becerisine sahip yönetici arayışına göndermede bulunmaktadır. Zira genellikle devlet otoritesine meydan okuyan koşulların ortaya çıktığı dönemlerde, yönetici arayışında mülkî memurlardan ziyade asker kökenlilerin isimleri öne çıkmaktadır. Asker kökenli yöneticiler, emniyet ve huzurun sağlanmasında görevlerinin sağladığı alt yapı ve donanım icabı daha uygun görülmektedir. Aslında asker ve sivil bürokrasi Tanzimat reformlarıyla yapısal anlamda birbirinden ayrıştırılmıştır. ${ }^{86}$ Bu bağlamda merkezî hükûmet, söz konusu reformlar gereği vilayet ve bağlı idarî birimlere askerî sınıfa mensup zatları atamaktan yana değildir. ${ }^{87}$ Ancak vilayette felaket hâlini almış kıtlık durumuna bağlı

82 BOA. ŞD, 2434/26, Lef. Lef. 5, 24 B 1297 (2 Temmuz 1880).

83 BOA. Y. A. HUS, 165/81, 6 N 1297 (12 Ağustos 1880).

84 Ağustos 1880'de Bağdat valisi Abdurrahman Paşa tarafindan merkezî hükûmete gönderilen bir raporda; mülkî amirlere yönelik bölgede çalışma deneyiminin “...zabıtlıklarında münhal vukuunda dahi umum jandarma idaresi canibinden merkezde toplanan ma'zul zabitlerin tayin ve iğramı arzu edilmesiyle ve halbu ki buranin adad ve mu'amelatına ve mevâki ve enhasına vâkıf olamayan o misüllü zabitan ile idare-i maslahat kabil ve sınıfi zabitanın muhafaza-i nizam ve intizamı mümkün olamayacağından..." ifadelerinde görüldüğü üzere askerî erkân için de vazgeçilmez bir ihtiyaç olduğu vurgulanmıştır. Bk.. BOA. Y. EE, 7/12, 24 L 1297 (30 Ağustos 1880).

85 Bouquet, Sultanın Paşaları 1839-1909, 438.

86 İlber Ortaylı, İmparatorluğun En Uzun Yüzyılı, (İstanbul: Timaş Yayınları, 2016), 154.

87 Tanzimat'la beraber idarî teşkilatlanmada modernleşmenin bir gereği olarak mülkîye sınıfı askerî sınıfın devlet yapısı içindeki ağırlığı karşısında genişletilmeye çalışılmıştır. 1859'da İstanbul'da açılan Mülkîye Mektebinin dar ölçekli yapısının Abdülhamid tarafından genişletilmesi de bu eğilimin bir sonucudur. Bk.. Findley, Kalemiyeden Mülkiyeye, 82,121; Ebubekir Ceylan, Ottoman Centralization And Modernization İn The Province Of Baghdad 1831-1872, (Doktora Tezi, Boğaziçi Üniversitesi, 2006), 156; Kırmızı, Abdülhamid 'in Valileri Osmanlı Vilayet Ídaresi 1895-1908, 87. 
olarak ortaya çıkan sorunlar, asker sınıfına mensup ve müşir düzeyinde bir zatı merkezî hükûmetin gündemine getirmiştir. Fuat Paşa'nın ismi bu gereklilikten hareketle ön plana çıkmış olmakla birlikte ataması yapılmamıştır. Atamanın hangi gerekçelerden dolayı gerçekleşmediği bilinmemektedir. Bununla birlikte askerî kökene mensup birini atama arayışı devam etmiştir. Bu arayışın sonucunda merkezî hükûmet, Eylül 1880'de bölgenin askerî erkânından Ferik rütbesini haiz Hacı Mehmed Paşa’yı vekâleten atamayı uygun görmüştür. ${ }^{88}$

Musul vilayet valiliğine vekâleten Ferik Mehmed Paşa atanırken Bağdat valiliğine Musulluların kendi vilayetlerine atanmasını çok istedikleri Takiyüddin Paşa atanmıştır. Bu atamalar, vilayet halkının memnuniyetiyle karşılanmıştır. ${ }^{89}$ Merkezî hükûmet yeni yöneticilerden kıtlığın yarattığı yaraların iyileştirilmesi ve devlet otoritesini alt üst eden Hemavend aşiret saldırılarının önlenmesini istemiş, Altıncı Ordu başkanlığına da gerekli desteğin verilmesini tavsiye etmiştir. Merkezî hükûmetin Hemavendlilere karşı bölgede âdeta bir seferberlik havası yaratmasının nedeni Eylül ayının ortalarında Bağdat'tan çıkan İstanbul Postasının Kerkük yakınlarında bulunan Çataldere mevkiinde Hemavendli bir grubun saldırısına uğraması ve bir hayli para ile eşyanın yağmalanmasıdır. ${ }^{90}$ Ancak Musul vilayetinin ekonomik ve askerî durumu parçalı ve birbirinden bağımsız bir şekilde hareket eden Hemavendli grupların saldırılarını önleyebilme imkânına sahip değildir. Öyle ki Ferik Mehmed Paşa, vekâleten görevlendirilmesinin ilk ayında vilayet merkezine oldukça yakın olmasına ve ulaşımı engelleyici coğrafi koşullar taşımamasına rağmen kıtlığın yol açtığı huzursuzlukları bastırmak amacıyla sefer tedariki yapılamaması nedeniyle Kerkük’ten Köysancak'a kolluk kuvvetlerini çıkaramamıştır. ${ }^{11}$ Vilayet sınırları içinde artan eşkıyalık eylemleriyle kırsal kesimde bulunan aşiret taşkınlıklarının oluşturduğu genel güvensizlik durumu Kerkük-Bağdat yolunu işlemez hâle getirmiştir. Musul vilayet merkezi Kerkük'ten Bağdat'a uzanan güzergâhın güvenliğine yönelik Hemavend saldırıları ve özellikle vilayet merkezine gönderilen yardımları ele geçirmek amacıyla çevre aşiretlerin yaptığı yağmalar, Musul vilayetinin imkânlarıyla önlenememiştir. Bunun üzerine merkezî hükûmet, vilayetin güven ve huzurunun sağlanması ve sarsılan devlet otoritesinin yeniden tesisi için Bağdat valisiyle Altıncı Ordu başkanlığından gerekli desteğin sağlanmasını istemiştir. $^{92}$ Bu kapsamda Musul vilayetinde bir kısım zaptiyenin maaş ve sefer ihtiyaçları merkezî hükûmetin emriyle Bağdat vilayeti tarafından karşılanmıştır. ${ }^{93}$

Ferik Mehmed Paşa, Bağdat valisi Takiyüddin Paşa ve Altıncı Ordu'nun sunduğu destekle vilayetin İran sınırı boyunca uzanan kuzey bölgelerinde devlet otoritesine meydan okuyan güçlü

88 BOA. Y. PRK. Arzuhal Jurnal (AZJ.), 3/96, 18 L 1296 (23 Eylül 1880); BOA. Y. PRK. ASK, 4/62, 24 Za 1297 (14 Kasim 1880).

89 BOA. Y. PRK. AZJ, 3/96, 18 L 1296 (23 Eylül 1880).

90 “... eşkıyayı merkumenin ta'addiyat ve i’nafatının ...hemen tedabir ve teşebbüsatı lazımeye mübaşeretle bunların ba'dema icrayl şekavete kudretyab olamayacak surette darb ve tenkilleriyle beraber gasb eyledikleri nukud ve sairenin dahi istirdadı ...” Bk.. BOA. BOE. VGG. d. 966, s. 143, 15 Za 1297 (15 Ekim 1880).

91 BOA. BEO. VGG. d. 966, s. 148, 9 Za 1297 (13 Ekim 1880).

92 BOA. BOE. VGG. d. 966, s. 143, 15 Za 1297 (15 Ekim 1880).

93 BOA. BEO. VGG. d. 966, s. 148, 9 Za 1297 (13 Ekim 1880). 
bir Hemavend grubunu liderleriyle yakalamayı başarmıştır. ${ }^{94}$ Uzun bir süre Hemavendlilere karşı herhangi bir teşebbüste bulunamamasına mukabil yeni yönetimin görünür bir irade ortaya koyması vilayet genelinde Ferik Mehmed Paşa'ya yönelik bir güven ortamı oluşturmuştur. Mehmed Paşa'nın, halkın kendisine yönelik teveccühünü hemen değerlendirmek istediği anlaşılmaktadır. Zira vilayetin ileri gelenleriyle bir mahzar tertip ederek başarılı bir yönetim sergilediği gerekçesiyle vekâleten yürüttügüü görevini asalete çevirmeye çalışmıştır. ${ }^{95}$ Ancak çok istemesine rağmen Mehmed Paşa'nın tüm çabaları sonuçsuz kalmış ve asaleten atamasına ilişkin herhangi bir gelişme olmamıştır. Muhtemelen Mehmed Paşa henüz merkezî hükûmetin takdirini kazanacak bir hizmet profili ortaya koyamamıştır. Çünkü vilayet alanında kıtlık felaketinin yarattığı yığınla sorun hâlâ çözülmeyi beklemektedir. Merkezî hükûmetin üst kurullarına Mehmed Paşa'nın başarılı bir yönetici olduğuna ilişkin mahzar giderken aynı zamanda Hemavend saldırılarından malları gasp edilen mağdurların mallarının iadesi ve asayişin sağlanması yönünde telgraflar da gönderilmektedir. ${ }^{96}$ Durum Aralık ayında daha da kötüleşmiştir. 1880 yılının Aralık ayında Hemavend aşiret gruplarının eylemleri Musul vilayet alanının dışına taşarak İranlı ziyaretçilerin yağmalanmasına kadar varmıştır. İran'dan Irak’taki türbeleri ziyarete gelen grupların, Hemavend aşiretinin saldırılarının hedefi olması ve Mendeli-Bağdat yol güvenliğinin sarsılması İran Devleti'nin bürokratik tepkisine neden olmuştur. Bu durum, merkezî hükûmetin Musul vilayet valisi üzerinde telkin ve baskılarının artmasına neden olmuştur. ${ }^{97}$

Ferik Mehmed Paşa, vekâleten yürüttüğü Musul vilayet valiliğini görevden alındığı Mayıs 1882 tarihine kadar merkezî hükûmetin takdirini celp edecek ve asaleten atanmasını sağlayacak şekilde yürütememiştir. Nitekim Hemavend aşiret gruplarının vilayet idaresini dört bir koldan felç eden saldırılarını önleyememiş ve Şeyh Ubeydullah ayaklanmasının Musul vilayet alanında oluşturduğu etkileri tam anlamıyla izale edememiştir. ${ }^{98} 1882$ yılı Ocak ayında şiddetlenen Hemavend saldırı ve yağmaları, merkezî hükûmetin Ferik Mehmed Paşa'ya yönelik art arda sert tebligatlar göndermesine neden olmuştur. ${ }^{99}$ Gönderilen uyarıların Ferik Mehmed Paşa tarafından dikkate alınıp alınmadığının yakından takibi görevi Bağdat valisi ve Altıncı Ordu Komutanlığına verilmiştir. ${ }^{100}$

94 BOA. BEO. VGG. d. 966, s. 151, 3 M 1298 (6 Aralık 1880).

95 Hut, Musul Vilayetinin İdari, İktisadi ve Sosyal Yapısı ( 1864-1909), 107.

96 “Daver vesair çend imza ile Kerkük'ten Hariciye Nezareti celilesine meb’us telgrafinda Hemavend eşkıyasının ta'adiyat-ı vakıasından şikâyetle gasb olunan eşyalarının istirdadı istid'a olunmakla...” Bk.. BOA. BEO. VGG. d. 966, s. 149, 20 Z 1297 (23 Kasim 1880).

97 "Ol havalinin muhafazai inzibatı ve vilayetin hüsn-i idaresi müstelzem olunduğundan buna itina olunması tavsiye olunur.” Bk.. BOA. BEO. VGG. d. 966, s. 151, 3 M 1298 (6 Aralık 1880).

98 Hut, Musul Vilayetinin İdari, İktisadi ve Sosyal Yapısı ( 1864-1909), 108.

99 “...dünkü telgrafnameler dahi tebliğ olunduğu üzere şekâvetin men’i ile hıfzı asayișe itina olunması pek ehem iduğünden ba'deizin dahi bu babta müsamaha olunur ise şediden mesul olacağınız bi 't-tekrar ihtar olunur." Bk.. BOA. BEO. VGG. d. 966, s.184, 12 S 1299 (3 Ocak 1882).

100 “....Hemavend eşkıyasılla diğerlerinin ta’addiyatı için tedâbir-i lazımeye müsara’at olunması zımnında Musul vilayeti vekâletine tebliğatı kat'iye ve ekide icra kılınmakla bu babda Băgdad valiliği ve kumandanlı̆̆ııın nezaret edilmesi...” Bk.. BOA. BEO. VGG. d. 966, s.185, 12 S 1299 (3 Ocak 1882). 
Merkezî hükûmetin kıtlığın etkilerinin yol açtığı sorunlarla mücadeleye yönelik birbirini takip eden ihtarlarına rağmen Musul vilayetinden Ferik Mehmed Paşa ve yönetimine yönelik mağduriyet ve şikâyet telgraflarının ardı arkası kesilmemiştir. Vilayet ileri gelenlerinden yirmi beş kişinin imzasıyla Kerkük’ten çekilen bir telgraf, 1880 kıtlığının vahametini ve vilayet yönetiminin bu konudaki başarısızlığını gözler önüne açıkça sermektedir. ${ }^{101}$

Musul vilayetinde kıtlığın yol açtığg açlık hâli ve buna bağlı meydana gelen ölümler, 1880 yılının son baharına kadar devam etmiştir. Sonbahardan sonra sağlanan bazı yardımlarla şehir merkezlerinde cereyan eden acı olayların önü alınabilmiş olsa da halk üzerinde etkisini artıran gıda yetersizliği 1882 baharına kadar sürmüştür. Bu süreçte toplumun yaralarının sarılamaması ve meydana gelen asayiş vakaları, Ferik Mehmed Paşa'yı tepkilerin merkezine oturtmuştur. Yukarıda bahsedilen telgrafın içeriğinden anlaşıldığı üzere vilayet ileri gelenleri kıtlığın toplum üzerinde yarattığg olumsuzlukları belli aralıklarla merkezî hükûmete bildirmişlerdir. Ancak merkezî hükûmetin bu konuda herhangi bir adım atmamış olması halkı hükümetten yana ümitsizliğe düşürmüştür. Kıtlık 1882 kışında hâl-i felaket boyutuyla devam etmiş ve Ferik Mehmed Paşa halkı teskin edecek etkili bir yönetim ortaya koyamamıştır. Bunun neticesinde merkezî hükûmet vilayet halkının artan tepkileri karşısında Mehmed Paşa'yı Mayıs 1882'de görevden almak zorunda kalmıştır.

\section{Sonuç}

Musul vilayetini teşkil eden Şehrizor (Kerkük), Süleymaniye ve Musul sancaklarında, 1877 yılında başlayan kuraklık, 1877-1878 Osmanlı Rus Harbi'nin ekonomik, siyasal ve toplumsal etkileri ve Şeyh Ubeydullah ayaklanmasının neden olduğu huzursuzlukların yanında 1879 Aralık ayından başlayarak şubata kadar etkisini sürdüren şiddetli soğuklar, 1880 yılının başından itibaren şiddetli bir açlığın yaşanmasına neden olmuştur. Osmanlı Devleti, tren, telgraf ve buharlı vapurların işlediği bir çağda her üç sancakta meydana gelen kıtlığa hazırlıksız yakalanmıştır. 1877'de etkisini göstermeye başlayan kıtlık ve buna bağlı meydana gelen asayişsizliğge karşı devlet, bu bölgeyi 1879'da Bağdat vilayetinden ayırarak müstakil bir vilayete dönüştürmüştür. Merkezi Kerkük olan Musul vilayetinin oluşumu, merkezî hükûmetin İran sınırıyla çevrili Kuzey Irak bölgesinin dûçar olduğu sorunlara karşı aldığı idarî bir tedbir olmuştur. Bu idarî tedbir, bölgenin karşılaştığı kıtlık durumuna karşı, mücadele etme hususunda yetersiz kalmıştır. Çünkü oluşturulan yeni vilayet, gerekli ekonomik ve askerî alt yapıdan yoksundu. Yapısal anlamda idarecilerin kendilerini gerçekleştirebileceği gerekli ekonomik ve askerî donanıma sahip olmaması, vilayeti tecrübeli valiler açısından kaçınılacak bir adres hâline getirirken valilik

101 "Su-i hal ve tedbirleriyle Musul vilayetini mahfeden vali vekiliyle merkez mutasarrlfinın ahvallerini ve bunların yüzünden dûçar olduğumuz mesaibin derecatına yazdı̆̆ımız mütte'addid 'arıza-i telgrafide arz ve tafsil kilınmış idi. İşin vilayetten sürülürse hakikat-ı hâle mugayyer cevap verileceği tabi'i olduğundan bu havalinin ve ma'ruzatımızın mündericatı hakkaniyet dairesinde tetkiki zımnında devletçe itimad olunur bir zatın tayiniyle i'zamına merhamet buyrulması ve şimdiye kadar yazlan istirhamnamemizden cevap alınmaması me 'yusunu muceb ise de yine adalet-i şahaneye müracaatla dûçar olduğumuz hâl-i felaketten istihlasımız istirhamından..." Bk.. BOA. Y. MTV, 8/87, 21 R 1299 (12 Mart 1882). 
deneyimi olmayan mülkî ve askerî yöneticiler için ise bir sınanma alanına dönüştürmüştür.

Musul vilayetinin yöneticiler açısından istenmeyen bir sınanma alanı olması, gerekli deneyim ve kabiliyete sahip olan yöneticilerin, vilayete tayin edilmelerine engel teşkil etmiştir. Atanması düşünülen zatların vilayet alanının kendi kariyerlerine zarar vereceğini düşünmeleri, merkezî hükûmetin Musul vilayetine valilik tecrübesini haiz yöneticileri atama çabasının çoğunlukla sonuçsuz kalmasına neden olmuştur. Bunun üzerine merkezî hükûmet valilik tecrübesi olmayan yöneticileri vilayete atamak durumunda kalmıştır. Kıtlık süreci boyunca Musul vilayetine vali olarak atanan her üç kişi de valilik tecrübesi olmayan yöneticilerdir. Feyzi Paşa ve Abdünnafi Efendi sivil kökenli yöneticiler olarak kıtlık sürecinin felaket haline evirildiği bir aşamada halkın mağduriyetini giderecek ve kıtlık koşullarını hafifletebilecek bir performans sergileyememişlerdir. Vilayet alanında kıtlıktan kaynaklı asayiş vakalarının artması üzerine merkezî hükûmet, Ferik rütbesiyle askerî bir yöneticiyi vekâleten vilayete vali olarak atamak durumunda kalmıştır. Ancak askerî sınıfa mensup olmasına rağmen söz konusu yönetici de herhangi bir varlık gösterememiştir. Kıtlık karşısında yöneticilerin varlık gösterememesi halkın tepkisini celp etmiş ve bu tepkiler belli bir seviyeye ulaştığında merkezî hükûmet, valileri değiştirme yoluna gitmiştir. Netice olarak vali değişimi, merkezî hükûmetin devlet olarak halkının maruz kaldığı afete karşı gerekli desteği sunamamasının alternatifi olarak başvurduğu bir çare şeklinde karşımıza çıkmıştır.

Hakem Değerlendirmesi: Dış bağımsız.

Çıkar Çatışması: Yazar çıkar çatışması bildirmemiştir.

Finansal Destek: Bu çalışma Mardin Artuklu Üniversitesi Bilimsel Araştırma Projeleri Koordinasyon Birimi tarafindan desteklenmiştir. (Proje no: MAÜ-BAP-18-EF-018)

Peer-review: Externally peer-reviewed.

Conflict of Interest: The author has no conflict of interest to declare.

Grant Support: This study was supported by the Scientific Research Projects Coordination Unit of Mardin Artuklu University. (Project number: MAÜ-BAP-18-EF-018)

\section{Kaynaklar/References}

Akyıldız, Ali, "Mahmud Nedim Paşa”, DİA, 27: 374-376. Ankara: Diyanet Vakfı Yayınları, 2003.

Bouquet, Oliver, Sultanın Paşaları 1839-1909, Çev. Devrim Çetinkasap, İstanbul: Türkiye İş Bankası Yayınları, 2016.

Braudel, Fernand, II. Felipe Döneminde Akdeniz ve Akdeniz Dünyası, Çev. Mehmet Ali Kıllıçbay, 1 cilt. Ankara: Doğubatı Yayınları, 2017.

Ceylan, Ebubekir, Ottoman Centralization And Modernization In The Province Of Baghdad 1831-1872, Doktora Tezi, Marmara Üniversitesi, 2006.

Çetinsaya, Gökhan, Ottoman Administration of Iraq, 1800-1908, London: SOAS/Routledge Studies on the Middle East, 2005. 
Davison, Roderic H, Osmanlı Imparatorluğu'nda Reform 1856-1876, Çev. Osman Akınhay, İstanbul: agora kitaplığı, 2005.

Dinç, Fasih, XIX. Yüzyılda Kerkük (Fiziki, İdari ve Sosyo-Ekonomik Yapı), Doktora Tezi, Firat Üniversitesi, 2016.

Edmonds, C. J, “The Kurds of Iraq”, The Middle East Journal, 11/1, (1957): 52-62.

Eisenstadt, S. N, Modernleşme başkaldırı ve değişim, Çev. Ufuk Coşkun, Ankara: Doğubatı Yayınları, 2004.

el Vardi, Ali, Lema 'at 'ül İctima 'iye, 3, cilt. Beyrut: Dare'l Raşid, 2005.

Findley, Carter V, Kalemiyeden Mülkîyeye Osmanlı Memurlarının Toplumsal Tarihi, Çev. Gül Çağalı Güven, İstanbul: Tarih Vakfı Yurt Yayınları, 1996.

Findley, Carter V, Osmanlı İmparatorluğunda Bürokratik Reform, Çev. Ercan Ertürk, İstanbul: Tarih Vakfı Yurt Yayınları, 2014.

Gráda, Cormac Ó, "Making Famine History”, Jorurnal Of Economic Literature, XLV, (2007): 5-38.

Gündüz, Ahmet, "Musul”, DİA, 31: 363-367. İstanbul: Diyanet Vakfı Yayınları, 2006.

Gündüz, Ahmet, "Süleymaniye”, DİA, 38: 111-113. İstanbul: 2010.

Gündüz, Ahmet, "Şehrizor”, DİA, 38: 473-475. İstanbul: Diyanet Vakfı Yayınları, 2010.

Gündüz, Emrah, Abdünnâfi Ifffet Efendi ve Divanı, Doktora Tezi, Atatürk Üniversitesi, 2018.

Hala, Fattah, The Politics of Regional Tarde in Iraq, Arabia and Gulf 1745-1900, Albany: State University of New York Press, 1997.

Hanioğlu, M. Şükrü, Bir Siyasal Örgüt Olarak Osmanlı İttihad ve Terakki Cemiyeti ve Jön Türklük, İstanbul: İletişim Yayınları, 1989.

Hut, Davut, Musul Vilayetinin İdari, İktisadi ve Sosyal Yapısı (1864-1909), Doktora Tezi, Marmara Üniversitesi, 2006.

Issawi, Charles, The Fertile Crescent 1800-1914 A ducumentary Economic History, London: Oxford University Press, 1988.

Ives, Dr. E, A Journey From Persia to England, London: 1773.

İnal, İbnülemin Mahmud Kemal, Son Asır Türk Şairleri, 2 cilt, İstanbul: MEB, 1969.

Kırmızı, Abdülhamit, Abdülhamid' in Valileri Osmanlı Vilayet İdaresi 1895-1908, İstanbul: Klasik Yayınları, 2016.

Longrigg, Stephen Hemsley, 'Irak, 1900 To 1950 A Political, Social, And Econmic History, London: Oxford Universty Prees, 1956.

Lorimer, J. G, Gazetteer Of The Persian Gulf, Oman And Central Arabia, I Volume, (Historical), Part I Chapters VI-IX, London: Achive Editions, 1986.

Marcus, Abraham, Modernliğin Eşiğinde Bir Osmanlı Şehri Halep, Çev. Mehmet Emin Baş, İstanbul: Küre Yayınları, 2013.

Nieuwenhu1s, Tom, Politics And Society In Early Modern Iraq Mamluk Pashas, Tribal Shayks and Local Rule Between 1802 and 1831, London: Martinus Nijhoff Publishers The Hague, 1982.

Ortaylı, İlber, İmparatorluğun En Uzun Yüzyıll, İstanbu: Timaş Yayınları, 2016.

Owen, Roger, The Middle East in the World Economy 1800-1914, New York: I.B. Tauris, 1993.

Pakalın, Mehmet Zeki, Osmanlı Tarih Deyimleri ve Terimleri Sözlüğ̈̈, 1 cilt, İstanbul: MEB, 1993.

Shields, Sarah D, Mosul Before Iraq Like Bees Making Five-Sided Cells, Albany: State University of New York Press, 2000. 
Talabani, Şeyh Rıza, Divan-ı Şeyh Rıza-yı Talabani, Bağdat: Çaphane-i Maarif, 1946.

Terzibaş1, Atâ, Kerkük Şairleri, Ankara: Ötüken Neşriyat, 2013.

Zabit, Şakir Sabır, Kerkük'te İçtima’i Hayat Folklor, Bağdat: Zaman Basımevi, 1964.

\section{Arşiv Kaynakları}

Türkiye Cumhuriyeti Devlet Arşivleri Başkanlığı Osmanlı Arşivi (BOA.), Bab-1 Ali Evrak Odası (BEO.) Vilayet Gelir Giden Defteri (VGG. d), 966, s. 21, 66, 94, 116, 118, 120, 126, 136, 143, 148, 149, 151, 156, 168, 184.

Türkiye Cumhuriyeti Devlet Arşivleri Başkanlığı Osmanlı Arşivi (BOA.), Bağdad Ayniyat, d. 851, 151, 5 Ca 1289 (11 Temmuz 1872).

Türkiye Cumhuriyeti Devlet Arşivleri Başkanlığ 1 Osmanlı Arşivi (BOA.), Dâhiliye Şifre (DH. ŞFR), 112/72, 21 N 1296 (8 Eylül 1879); DH, ŞFR, 111/27, 18 Ca 1296 (10 Mayıs 1879); DH, ŞFR, 119/6, 1 L 1296 (28 Eylül 1878); DH. ŞFR, 111/96, 26 B 1296 (16 Temmuz 1879); DH. ŞFR, 112/50, 5 N 1296 (23 Ağustos 1879); DH. ŞFR, 113/54, 23 Ca 1297 (3 Mayıs 1880).

Türkiye Cumhuriyeti Devlet Arşivleri Başkanlığı Osmanlı Arşivi (BOA.), Hariciye Nezareti Tahrirat (HR TH.), 34/28, 17 Ca 1297 (27 Nisan 1880).

Türkiye Cumhuriyeti Devlet Arşivleri Başkanlığı Osmanlı Arşivi (BOA.), Hariciye Nezareti Tercüme Odası (HR TO.), 258/30, (19 Ocak 1880).

Türkiye Cumhuriyeti Devlet Arşivleri Başkanlığı Osmanlı Arşivi (BOA.), Hariciye Siyasi (HR. SYS), 2942/ 19, 13 Ş 1296 (2 Ağustos 1879).

Türkiye Cumhuriyeti Devlet Arşivleri Başkanlığı Osmanlı Arşivi (BOA.), İrade Dâhiliye (İ. DH), 781/63488, 16 S 1296 (9 Şubat 1879); İ. DH, 812/65561, 22 N 1297 (28 Ağustos 1880); İ. DH, 802/65028, 16 Ca 129 (26 Nisan 1880); İ. DH, 782/63625, 29 Ra 1296 (23 Mart 1879); İ. DH, 633/47598, 8 Ra 1291 (25 Nisan 1875).

Türkiye Cumhuriyeti Devlet Arşivleri Başkanlığı Osmanlı Arşivi (BOA.), İrade Mesail-i Mühimme (İ. MMS), 62/2915, Lef. 2, 17 C 1296 (8 Haziran 1879); İ. MMS, 60/2850, 21 S 1296 (14 Şubat 1879); İ. MMS, 64/3040, 4 Ca 1296 (26 Nisan 1879).

Türkiye Cumhuriyeti Devlet Arşivleri Başkanlığı Osmanlı Arşivi (BOA.), İrade Mevlis-i Vâlâ (İ. MVL.) 387/16890, Lef. 13, 9 Za 1273 (29 Haziran 1857).

Türkiye Cumhuriyeti Devlet Arşivleri Başkanlığı Osmanlı Arşivi (BOA.), Maarif Mektubi Kalemi (MF. MKT.), 71/72, 12. 11. 1298 (6 Ekim 1881).

Türkiye Cumhuriyeti Devlet Arşivleri Başkanlığı Osmanlı Arşivi (BOA.), Sadaret A.).d. 982, Numara 48, 23 Şubat 1298 (7 Mart 1883).

Türkiye Cumhuriyeti Devlet Arşivleri Başkanlığı Osmanlı Arşivi (BOA.), Şurâ-yı Devlet (ŞD.) 2434/26, 21 C 1297 (31 Mayıs 1880).

Türkiye Cumhuriyeti Devlet Arşivleri Başkanlığı Osmanlı Arşivi (BOA.), Y. PRK. Arzuhal Jurnal (AZJ.), 3/96, 18 L 1296 (23 Eylül 1880).

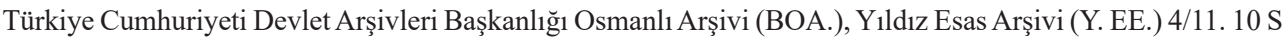
1296 (3 Şubat 1879); Y. EE. 7/12. 24 L 1297 (30 Ağustos 1880); Y. EE. 12/8, 25 B 1296 (15 Temmuz 1879).

Türkiye Cumhuriyeti Devlet Arşivleri Başkanlığı Osmanlı Arşivi (BOA.), Yıldız Mütenevvî Maruzat Evrakı (Y. MTV.), 3/129, 24 C 1297 (3 Haziran 1880); Y. MTV, 8/87, 21 R 1299 (12 Mart 1882); Y. MTV, 3/86, Lef. 2, 29 Ca 1297 (9 Mayıs 1880). 
Türkiye Cumhuriyeti Devlet Arşivleri Başkanlığı Osmanlı Arşivi (BOA.), Yıldız Perakende Evrakı Askeri Maruzat (Y. PRK. ASK.), 4/62, 24 Za 1297 (14 Kasım 1880); Y. PRK. ASK, 4/55, 17 Za 1297 (21 Ekim 1880).

Türkiye Cumhuriyeti Devlet Arşivleri Başkanlığı Osmanlı Arşivi (BOA.), Yıldız Sadaret Hususi Maruzat Evrak1 (Y. A. HUS.), 164/63, 22 Ca 1297 (2 Mayıs 1880); Y. A. HUS, 165/81, 6 N 1297 (12 Ağustos 1880).

Further Correspondence Respectin The Condition Of The Popülation İn Asia Minor And Syria, Turkey No: 23 (1880), London 1880.

Musul (Vilayet) Gazetesi (MG), Sayı 507.

Özcoşar İbrahim, H. Hüseyin, Güneş, Fasih Dinç, 242 Nolu Mardin Şer'iye Sicili Belge Özetleri ve Mardin, İstanbul: İhtisas Kütüphanesi Yayınları, 2006. 
